\title{
Private Equity and Financial Fragility during the Crisis
}

\section{Citation}

Bernstein, Shai, Josh Lerner, and Filippo Mezzanotti. "Private Equity and Financial Fragility during the Crisis." Harvard Business School Working Paper, No. 18-005, July 2017.

\section{Permanent link}

http://nrs.harvard.edu/urn-3:HUL.InstRepos:33840637

\section{Terms of Use}

This article was downloaded from Harvard University's DASH repository, and is made available under the terms and conditions applicable to Open Access Policy Articles, as set forth at http:// nrs.harvard.edu/urn-3:HUL.InstRepos:dash.current.terms-of-use\#OAP

\section{Share Your Story}

The Harvard community has made this article openly available.

Please share how this access benefits you. Submit a story.

\section{Accessibility}




\section{Private Equity and Financial Fragility during the Crisis}

Shai Bernstein Josh Lerner

Filippo Mezzanotti

Working Paper 18-005 


\title{
Private Equity and Financial Fragility during the Crisis
}

\author{
Shai Bernstein \\ Stanford University \\ Josh Lerner \\ Harvard Business School \\ Filippo Mezzanotti \\ Northwestern University
}

Working Paper 18-005 


\title{
Private Equity and Financial Fragility during the Crisis
}

\author{
Shai Bernstein, Josh Lerner and Filippo Mezzanotti*
}

July 18,2017

\begin{abstract}
Do private equity firms contribute to financial fragility during economic crises? We find that during the 2008 financial crisis, PE-backed companies increased investments relative to their peers, while also experiencing greater equity and debt inflows. The effects are stronger among financially constrained companies and those whose private equity investors had more resources at the onset of the crisis. PE-backed companies consequentially experienced higher asset growth and increased market share during the crisis.
\end{abstract}

\footnotetext{
*Stanford University and National Bureau of Economic Research (NBER); Harvard University and NBER; Northwestern University. We thank the Harvard Business School's Division of Research for financial support. We also thank seminar participants at Columbia, Duke, LBS, MIT, and Northwestern for helpful comments, especially Sabrina Howell, David Robinson, and Morten Sorensen. One of the authors has advised institutional investors in private equity funds, private equity groups, and governments designing policies relevant to private equity. All errors and omissions are our own. Emails: shaib@stanford.edu, josh@hbs.edu, and filippo.mezzanotti@northwestern.edu.
} 


\section{Introduction}

The recent global financial crisis increased the attention paid by policy makers, regulators, and academics to financial stability. While much attention has been devoted to deficiencies in the banking system in this and earlier crises (Bernanke and Gertler, 1990; Reinhart and Rogoff, 2009; and Fahlenbrach, Prilmeier, and Stulz, 2012), high levels of corporate debt have also triggered concerns. Highly leveraged firms may enter financial distress during a crisis, exacerbating cutbacks in investment and employment and contributing to the persistence of the downturn (Bernanke, et al., 1988; and Bernanke, 1983).

The practices of the private equity (PE) industry in particular have raised concerns. In the three years leading up to the crisis (between 2006 and 2008), global PE groups raised almost $\$ 2$ trillion in equity ${ }^{1}$, with each dollar typically leveraged with more than two dollars of debt (Kaplan and Stromberg, 2009). This phenomenon was not confined to the recent crisis. Private equity markets are prone to distortions introduced by credit cycles. As documented by Axelson, et al. (2013), periods characterized by booming financial markets also experienced greater private equity fundraising, higher transaction valuations, and critically more leverage.

The impact of PE investment patterns on the economy during periods of financial turmoil, however, remains poorly understood. On the one hand, the cyclicality of private equity activity, combined with the leveraging of their portfolio companies, may exacerbate the negative effects of shocks to the financial sector, aggravating the boom and bust dynamic of the economy. In line with this idea, the Bank of England suggests that buyouts should be monitored for macroprudential reasons, because "the increased indebtedness of such companies poses risk to the

\footnotetext{
${ }^{1}$ http://www.preqin.com
} 
stability of the financial system. ${ }^{2}$ Moreover, the pressure to complete deals during boom times may lead to the financing of lower-quality firms (Kaplan and Stein, 1993), leaving PE-backed companies more exposed to changes in underlying economic conditions. Finally, the increased fundraising and investment during boom periods may reduce the ability of private equity groups to effectively monitor and fund their portfolio companies once economic conditions deteriorate. These concerns have led to efforts to cap the amount of leverage used in PE transactions by the U.S. Federal Reserve Bank and the European Central Bank.

Alternatively, PE-backed companies may be resilient to downturns, and therefore play a stabilizing role during bad times. In particular, these companies may be better positioned to obtain external funding when financial markets are dysfunctional. First, PE groups have strong ties with the banking industry (Ivashina and Kovner, 2011) and may be able to use these relationships to access credit for their firms during periods of crisis. Second, because PE groups raise funds that are drawn down and invested over multiple years - commitments that are very rarely abrogatedthey may have "deep pockets" during downturns. These capital commitments may allow them to make equity investments in their firms when accessing other sources of equity is challenging.

Motivated by these alternative hypotheses, this paper seeks to understand whether private equity contributed to the fragility of the economy in the United Kingdom (UK) during the recent financial crisis. The UK is a perfect environment to study this question. First, the UK had the largest private equity market as a share of GDP before the crisis (Blundell-Wignall, 2007) — with $\mathrm{PE}$ assets at about $11 \%$ of $\mathrm{GDP}^{3}$ - and one of the largest in absolute value. In line with these numbers, the Bank of England estimated that before the crisis, PE-backed companies had issued

\footnotetext{
${ }^{2}$ Bank of England Quarterly Bulletin, 2013Q1

${ }^{3}$ This number is obtained by dividing the total fundraising between 2004 and 2008, as estimated by the European Venture Capital Association and PEREP Analytics, by GDP in 2008 (as reported by the World Bank).
} 
more than $10 \%$ of all non-financial corporate debt in the UK. ${ }^{4}$ Second, the UK provides detailed income statement and balance sheet information for almost every active company, whether public or private (Brav, 2009; and Michaely and Roberts, 2012). Similar financial data are not available in the United States. Finally, the UK experienced a severe credit market freeze during the 2008 crisis, with a dramatic decline in private sector investment and lending (Riley, Rosazza, Bondibene, and Young, 2014). As illustrated in Figure 1, aggregate investment declined by more than $20 \%$ during 2008 in the UK, which simultaneously experienced a sharp credit contraction (Figure 2).

To address the above questions, we study the relative evolution of PE-backed and non-PE companies in the wake of the financial crisis. We focus on the financial decisions and performance of these firms during this period, in an attempt to understand whether private equity exacerbates or dampens the sensitivity of the economy to credit cycles.

Our main analysis focuses on a final sample of almost five hundred companies that were backed by PE prior to the financial crisis. Using a difference-in-difference approach, we study how the financial decisions and performance of the PE-backed companies were affected by the onset of the crisis relative to a control group. The control group employs companies that were operating in the same industry as the PE-backed companies and had similar size, leverage, and profitability in 2007, following the methodology of Boucly, Sraer, and Thesmar (2011). ${ }^{5}$ The matching firms had similar trends in the years leading to the crisis along dimensions such as investment, revenue, returns on assets, equity contributions, and debt issuances. Therefore, this approach allows us to

\footnotetext{
${ }^{4}$ Bank of England Quarterly Bulletin, 2013Q1

${ }^{5}$ As we discuss in the paper, the main results are confirmed also when using a similar matching procedure but excluding leverage as a matching variable.
} 
explore differences that stem from organization structure, rather than their balance sheet or investment characteristics.

We start by comparing the PE-backed companies and their peers' behavior during the financial crisis. We find that PE-backed companies decreased investments less than non-PEbacked companies did during the financial crisis, with between five and six percent greater spending, an effect that is strongly statistically significant. Looking at the timing of the effects, the two groups did not differ significantly in the pre-crisis period, but the investment rate of the PE group substantially diverged from the control group beginning in 2008. In fact, the divergence of the PE group occurs exactly when aggregate investments and credit growth in the UK started to decline sharply.

We then show that the higher investments by PE-backed companies reflect the fact that these firms appear to have been less bound by financial constraints. We find that debt issuance over assets was four percentage points higher for PE-backed companies during the crisis, and similarly, equity issuances over assets increased by two percentage points relative to their peers. At the same time, the cost of debt, measured by interest expense over total debt, was relatively lower for PE-backed companies during the crisis. As before, these effects appeared first in 2008 and continued through the remainder of the period (with varying levels of statistical significance).

The idea that private equity firms can help relax the financial constraints of portfolio companies is also consistent with two additional findings. First, the positive effect on investment is particularly large among companies that were ex-ante more likely to be financially constrained during the crisis. We find this result using various proxies of financial constraints, such as size, industry dependence on external finance (Rajan and Zingales, 1998), and pre-crisis leverage. 
Second, the increase in investment is larger when the private equity sponsor had more resources available at the onset of the crisis to help the portfolio company. To explore this dimension, we exploit the heterogeneity across private equity firms. First, we focus on the amount of dry powder - capital raised but not yet invested - that is available to investors at the time of the financial crisis. Second, we look at to whether their most recent fund was at an earlier stage at the time of the financial crisis. These tests are based on the underlying assumption that PE firms that are at the early years of their fund and with more dry powder have more resources—-both financial and operational — to invest in their portfolio companies during the crisis. Our results confirm this hypothesis.

Taken together, these results illustrate that PE-backed companies do not appear to be more sensitive to the onset of the financial crisis. Rather, during a period in which capital formation dropped dramatically, PE-backed companies invested more aggressively than peer companies did. This ability to maintain a high level of investment appears related to the superior access of PEbacked companies to financing, in terms of both equity and debt issuances, and the lower cost of debt.

The results are robust to a battery of checks. Throughout the analysis, we control for firm fixed effects, and thus remove time-invariant characteristics of the control and treatment firms. We also show that the results are not driven by non-parallel trends in the pre-crisis period and they are not affected by the addition of company controls. Second, our main results generally do not change when we exclude companies whose private equity deals were management buyouts (MBOs), a class of transactions in which the engagement of private equity firms is traditionally lower. Third, it does not appear that the results simply reflect differences in attrition between PE and non-PE companies. Fourth, the results remain unchanged if we control for time-varying industry shocks 
around the crisis. Lastly, we also confirm that the results are robust to alternative matching estimators. In particular, we find that removing leverage from the variables used to match companies does not affect our results.

In the final part of the paper, we examine the performance of PE-backed companies during the financial crisis. We find that PE-backed companies experienced a greater growth in their stock of assets in the years after the crisis, consistent with the greater investment seen above. Similarly, we find that PE-backed companies increased their market share in the industry during the crisis. At the same time, PE-backed companies did not underperform their peers: that is, they did not become relatively less profitable, whether measured by the ratios of EBITDA to revenue or net income to assets. These findings are contrary to what would be expected if companies were pursuing value-destroying investments during this period.

We also examine the exit patterns of PE-backed companies relative to the control group during the crisis period. We find that PE-backed companies were not more likely to go bankrupt, but they were more likely to be sold through non-distressed M\&A transactions. Overall, these results regarding exits-while by their nature limited - again seem to be inconsistent with the hypothesis that PE financing increases the financial fragility of the portfolio firms.

This paper relates to an extensive body of work examining the behavior of financial institutions during the financial crisis and their consequences for operating firms (e.g., Ivashina and Scharfstein, 2010; and Ben-David and Franzoni, 2012). The conclusions, though, are more benign here than many of the studies examining other financial institutions, including banks, rating agencies, and hedge funds. The role of private equity groups seems more akin to those of the Japanese banks during the 1980s documented by Hoshi, Kashyap, and Scharfstein $(1990,1991)$, where better information and aligned incentives allowed bank-affiliated firms to overcome the 
capital constraints that limited investments of their peers without such relationships. During the financial crisis, the greater alignment and relatively longer time horizons of private equity investors may have allowed firms to more successfully respond to the economic dislocations. ${ }^{6}$ The paper is also related to an extensive literature that explores the effects of private equity ownership on firm outcomes (e.g., Bernstein, et al., 2016; Bernstein and Sheen, 2016; Boucly, Sraer, and Thesmar, 2011; Cohn and Towery, 2013; Davis, et al., 2013; John, Lang, and Netter, 1992; Kaplan, 1989; and Lichtenberg and Siegel, 1990).

The paper is organized as follows. In Section 2, we present the data used in this study. Section 3 then describes the empirical approach employed in the paper. Sections 4 and 5 present the main results on investment and performance, discussing the possible mechanisms behind our results and presenting a battery of robustness tests. Finally, Section 6 summarizes our results and conclusions.

\section{Data}

\subsection{Sample Construction}

We start our data construction by extracting from Capital IQ all UK companies backed by private equity before the financial crisis. We identified private equity deals in Capital IQ by searching for events such as "going private," "leveraged buyout," "management buyout," and "platform.” In so doing, we excluded "growth buyouts," "venture capital" and "expansion capital" investments, where investors generally buy a stake in the company using little or no leverage. Since we are interested in studying the behavior of UK PE-backed companies around

\footnotetext{
${ }^{6}$ The high-degree of diversification among different types of limited partners (LP) of buyout funds may explain why they were able to support their portfolio companies during the crisis. In contrast, Illig (2012) argues that that venture capital funds had difficulties in raising capital and had to defer capital calls during the crisis because their LPs base was less diversified and more concentrated among endowments.
} 
the financial crisis, we selected only firms that (i) were headquartered in United Kingdom at the time of the deal; (ii) had received a PE investment by the end of 2007 and (iii) did not experience an exit by the PE group by the end of $2008 .^{7}$

We then further filter our data, keeping only those firms that had balance sheet and income statement information in Amadeus, a Bureau Van Dijk (BvD) data set of European companies. Amadeus collects data from the "Companies House," the United Kingdom official national registrar office. As already pointed out by other authors (Brav, 2009; Michaely and Roberts, 2012), the United Kingdom is a perfect setting for studies of private companies. According to current regulations, every registered limited company is required to provide financial and income information annually to the public register.

The extent of the requirement to disclose financial information in the UK, however, varies with the size of the company. Small (and some medium-sized) companies are allowed to file abbreviated accounts. ${ }^{8}$ Since the amount of information small firms disclose to Companies House (and hence in the Amadeus dataset) is quite limited, we excluded this group from our analysis. The reliability of the source and its coverage of the remaining private firms is a key strength of our study. Most of the companies in our sample consist of middle-sized private enterprises, for which similar financial data are not available in the United States. ${ }^{9}$

We supplement Amadeus data with Orbis, another data product from BvD. While both Amadeus and Orbis collect information from the Companies House, Amadeus generally removes firms from the sample after a few years of inactivity. This is not the case for Orbis. Since the post-

\footnotetext{
${ }^{7}$ During 2008, there were 28 exits of PE firms. The results remain unchanged if we include them in the sample.

${ }^{8}$ Since 2008, a small company is defined as one meeting at least two of the following criteria: total assets less than $£ 3.26$ million, annual turnover less than $£ 6.5$ million, and an average number of employees fewer than 50 . This group usually reports only assets, revenue, and profits.

${ }^{9}$ One limitation of this data set is that balance sheet items are always reported at the book value.
} 
financial crisis period was characterized by an increase in firm exit, using only Amadeus would have generated selection concerns that could undermine the reliability of our results. ${ }^{10}$

Therefore, we further restrict the sample to firms meeting the following criteria: (i) matched to Amadeus; (ii) not a small firm, as defined by the Companies House; and (iii) not operating in the financial (SICs 600-699), public (SICs 900-999), or utility sectors ( SICs 489493). ${ }^{11}$ This led to an initial sample of 987 unique firms. Once we exclude firms that did not meet minimum data requirements for the matching process described below, the sample includes 722 firms. ${ }^{12}$

\subsection{Other Data}

We supplement the data from Amadeus/Orbis to identify potential acquisitions and bankruptcies during the crisis. We start by constructing two different variables that identify whether a firm went out of business. In particular, we generate a dummy "Out of Business," which is equal to one if the firms' information is missing in Amadeus/Orbis by 2011, suggesting that the firm no longer exists. ${ }^{13}$ On its own, the interpretation of this variable is unclear, since a firm can exit from the company registry for many different reasons, such as bankruptcy or acquisition.

We thus further refine this measure by generating a dummy — "Bad Exit"— that identifies companies that went out of business unambiguously because of distress. We generate this variable using the firm status history, available through Orbis. The data provider collects information from

\footnotetext{
${ }^{10}$ Orbis and Amadeus are essentially the same data product. The main two differences are the deletion of exited firms, as discussed above, and the interface used to distribute the data.

${ }^{11}$ This industry sample selection is common to the private equity literature. Similarly, Michaely and Roberts (2012) apply similar filter with the same data set.

${ }^{12}$ We require that companies have data on industry, return on assets, capital expenditures, asset, and leverage in 2007.

${ }^{13}$ In particular, we look at the total assets variable to identify company exits. Information on total assets is always required by UK reporting rules, and therefore when this field is missing, the company no longer exists.
} 
the Companies House and assigns to each firm a status, such as active, dissolved, dormant, or in liquidation, which may change over time. We define a company status as a "bad exit" if (a) the firm was not active by 2011 and (b) before disappearing from the data, its status implied that the firm was in liquidation or in insolvency proceedings.

Similarly, we use Capital IQ to identify potential profitable exits by looking at firms involved in M\&A transactions from 2008 onwards. Since M\&A transactions may also arise because of distress, we provide an alternative measure by excluding companies that were involved in M\&A but were also identified in the same period as in distress, as discussed above.

Lastly, we also collect information on the history of the PE investors for each portfolio company, in order to identify when the PE investors raised their last fund before the crisis. The younger the last fund at the onset of the crisis, the more likely that the private equity firm will have more financial and operational resources available, since the PE firm had less time to deploy capital and commit time to existing portfolio companies. In order to compile this information, we manually search the private equity firms in ThomsonOne and Capital IQ and collect information about their fundraising history. ${ }^{14}$

We also construct a measure of PE firm "dry powder," a proxy for the dollar amount of financial resources that the PE investors have available by the time of the crisis. To generate this measure, we collect in ThomsonOne the fundraising and investment history for the PE investors during the 2001-2007 period, and calculate aggregate fundraising and investments. ${ }^{15}$ The dry

\footnotetext{
${ }^{14}$ If a portfolio company has more than one PE firm, we conservatively use the most recent fundraising year among all investors.

${ }^{15}$ In order to measure capital investments of PE investors, we sum the total equity investment made over the specified period. The estimated equity investment in each case is estimated in the following manner. If available, we use the estimated equity investment as reported by ThomsonONE. When this is not available, we estimate the equity investment by the fund as the total amount of equity invested in the firm divided by the total number of funds investing in the round. When ThomsonONE does not report the total equity invested, we use the value of the deal minus the debt (we assume debt to be zero when missing). Since the fund used for investment is not always reported, we use the total investment made by the PE group over the period.
} 
powder measure is the difference between the PE firm fundraising and investment. Using this variable, we construct a dummy "high dry powder" that is equal to one if the company's PE investors are in the top quartile for dry powder. If a company has more than one PE, we use the shareholder with most resources.

\section{$3 \quad$ Empirical Strategy}

To understand how the crisis affected the financial and investment policies of PE-backed companies, we develop a difference-in-difference design where we compare PE-backed companies to a control group of non-PE backed companies around the financial crisis. We first describe how we construct the sample of matched firms and then discuss the empirical specification.

\subsection{Constructing a Matched Control Group}

Private equity-backed companies are clearly not a random sample of the population: for instance, they are likely to be larger and more leveraged than the average firm. Therefore, the first step in the analysis is to identify a proper control group for the set of PE-backed companies.

Following Boucly, Sraer, and Thesmar (2011), we identify a suitable control group through a matching procedure for each PE-backed company in our sample. We identify a set of control firms that operate in the same industry and had a similar size, leverage, and profitability in 2007. This procedure involved two steps. First, for all private equity-backed companies in our data, we selected every company in the Amadeus/Orbis sample that (a) belonged to the same two-digit SIC;

(b) had a return on assets (ROA), defined as net income over total assets, within a $30 \%$ bracket around our PE firm; (c) had assets within a 30\% bracket around our PE firm; and (d) had leverage 
within a 30\% bracket around our PE firm. Second, if this first step identified more than five firms, we selected the closest five, based on quadratic distance computed based on the variables.

Overall, this procedure is a more conservative version of Boucly, Sraer, and Thesmar (2011), since we add an additional variable to the matching — leverage — and use a narrower matching bandwidth. ${ }^{16}$ Using this methodology, we were able to match 434 of the 722 firms, generating a total sample of 1,984 firms. In the robustness section, we present an alternative matching procedure that is closer to Boucly, Sraer and Thesmar (2011), by eliminating leverage in the matching procedure. ${ }^{17}$

For every firm in the final sample, we extract from Amadeus/Orbis the full set of income and financial information available for the period from 2004 to 2011. Using these data, and following Brav (2009) and Michaely and Roberts (2012), we construct several measures of firm activity. In particular, we calculate capital investments as the change in assets plus the reported depreciation. Furthermore, we identify equity injections in the company by measuring the change in equity minus profit. Similarly, debt issuance is computed as the change in total liabilities in the year. All these variables are normalized by total assets. In addition, we measure firm leverage as total liabilities over total assets, and cost of debt as the ratio of total interest expenses to total debt. In order to limit the influence of outliers, we winsorize all ratios at $1 \%$. The Data Appendix provides more information about the variables and the sample.

Panel A of Table 1 shows the industry distribution of PE-backed companies in the sample. We compare it with the universe of the UK firms, after we eliminate small businesses and

\footnotetext{
${ }^{16}$ The other difference is that we measure size in terms of assets and not employment. The reason for this choice is that employment variable in Amadeus is significantly less populated than assets. However, in a robustness test, we added employment as a fourth variable in our matching procedure and show that this does not affect the results. ${ }^{17}$ In a previous version of the paper, we have used wider matching boundaries ( $50 \%$ instead of $\left.30 \%\right)$, which is in line with Boucly, Sraer, and Thesmar (2011). In general, these changes increase the size of our final sample and marginally reduced the quality of the matches, but did not affect the main results.
} 
companies in the financial or regulated sectors. The majority of the sample firms are in either the services $(38 \%)$ or manufacturing $(32 \%)$ industries. Other important industries include wholesale trade, construction, and retail. The sample industry distribution is relatively close to the universe of companies: the major difference is that PE-backed companies tend to be more concentrated in manufacturing, and less represented in the construction industry and services. Both treatment and control samples have the same industry distribution due to the matching procedure.

In Panel B of Table 1, we compare the characteristics of firms in the treatment and the matched control group in 2007. The average firm in the sample is a mid-sized firm with around $\$ 80$ million in revenue. Across the two groups, firms have very similar ROA, investment, leverage, and equity and debt issuances. These differences are insignificant, with small economic magnitude. The only exception is that PE-backed companies are slightly larger than the control group in terms of revenue. Overall, this matching procedure suggests that differences in funding patterns across the treated and control groups mostly disappear when we compare firms with similar sizes, leverage ratios, and profitability within the same industry. ${ }^{18}$

Since this paper relies on a difference-in-difference analysis, it is important to explore the assumption of pre-crisis parallel trends. We explore whether this assumption holds in the observables in Panel C. In particular, we compare one and two-year growth rates ending in 2007 for the main firm characteristics considered so far. We find that the differences in the growth rates between the two groups are not significantly different from zero across all observables. Similar patterns can be seen graphically in Figures 3, 4, and 5, in which both treatment and control firms follow similar trends in the years leading to the crisis.

\footnotetext{
${ }^{18}$ One residual concern regards the presence of listed firms in the control group. In principle, listed firms may have been differentially affected by the financial crisis and this feature may have partially affected the result. However, we have only 19 control firms $(<2 \%)$ that are public.
} 
Overall, these analyses suggest that PE-backed companies were similar in 2007 to the control group. In principle, this is not a necessary condition for our identification-which instead hinges on the presence of parallel trends between the two groups - but it allows us to exclude the possibility that differences in behavior around the crisis were due to differences in other observable characteristics. Later in the paper, we further show that our results are also stable when we augment our model with a set of controls for firm characteristics in 2007, which should absorb any residual differences in observables across the two groups.

Moreover, the two groups present similar growth paths before the crisis, which alleviate concerns that PE-backed companies were outperforming the control group before the crisis. As we discuss below, our estimates are consistent with the assumption of parallel trends between treated and control groups during the pre-crisis period leading to the crisis, the main identification assumption in our difference-in-difference design. A more formal and direct test of the parallel trend assumption will be discussed in Section 4.

\subsection{Identification Strategy}

We estimate this model using a panel data set from 2004 to 2011, a symmetric window around the 2008 shock. ${ }^{19}$ The choice of 2008 as the first year of the crisis is in line with a large body of empirical evidence on the crisis (e.g., Duchin, Ozabas, and Sensoy, 2010; Kahle and Stulz, 2013), as well as official statistics on the UK provided by the Bank of England. As we show in Figure 1, aggregate investment in the UK declined by more than $20 \%$ between the beginning of

\footnotetext{
${ }^{19}$ For consistency, both PE-backed companies and each corresponding control group enter in the sample at the same time, which is 2004 or the year of the PE deal if after 2004.
} 
2008 and mid-2009. At the same time, credit availability experienced a sharp contraction starting in the first quarter of 2008 (Figure 2). ${ }^{20}$ We estimate the following equation:

$$
y_{i t}=\alpha_{t}+\alpha_{i}+\beta_{1}\left(\text { PE } \text { firm }_{i} * \text { Crisis }\right)+\theta X_{i t}+\varepsilon_{i t}
$$

where $y_{i t}$ is an outcome variable measured for company $i$ at time $t,\left(\alpha_{i}, \alpha_{t}\right)$ are a set of company and year fixed effects, $P E$ firm $_{i}$ is a dummy for the companies that are backed by PE investors, and Crisis is a dummy for the period from 2008 to 2011. Furthermore, we augment our specification with a set of firm covariates $X_{i t}$. Lastly, we cluster standard errors at the firm level (Bertrand, Duflo, and Mullainathan, 2004).

The inclusion of firm fixed effects removes time-invariant differences between treatment and control firms. However, the causal interpretation of the results crucially depends on the parallel trend assumption. In particular, we need to assume that PE-backed companies would have experienced the same change in behavior as non PE-backed companies in the absence of the financial crisis. ${ }^{21}$ The parallel trend assumption is intrinsically untestable, since we cannot observe the true counterfactual in the absence of the shock. However, we can strengthen the interpretation of our analysis by providing evidence consistent with this assumption, exploring pre-shock trends.

First, it is important to recognize that our treatment and control groups are similar, at least in terms of observable characteristics. By construction, both groups have the same industry distribution, and as we discussed before, profitability, investment, and leverage are similar across these groups. Even more importantly for the parallel trend assumption, the PE and non-PE companies have similar growth rates in the years leading up to the crisis, as we illustrate below.

\footnotetext{
${ }^{20}$ Statistics are taken from the Bank of England “Trends in Lending - April 2009” (2009).

${ }^{21}$ For instance, it would be problematic if treated firms differed from untreated firms along some characteristics that would be affected by the financial shock independently from their status as a PE-backed company.
} 
Pushing this argument one step further, we can formally examine the time-varying behavior of the treatment effects for the main outcomes in our analysis by estimating:

$$
y_{i t}=\alpha_{t}+\alpha_{i}+\sum \beta_{k}\left(P E \text { firm }_{i}\right)+\theta X_{i t}+\varepsilon_{i t}
$$

where we estimate a different $\beta_{k}$ for every year between 2004 and 2011, using the last year before the crisis, 2007, as the reference year. If our parameter $\beta_{k}$ in the standard equation is correctly capturing the causal effect of the crisis on private equity firms - rather than a differential trend between the two groups - then we expect the effect of private equity to appear only at the onset of the crisis. In the next section, we will show evidence consistent with this argument.

In the paper, we take two additional steps to strengthen the analysis further. First, we augment our specifications with controls that capture the heterogeneity across firms in important characteristics before the crisis. In particular, we control for firm size (log of revenue), growth of revenue, normalized cash flow (cash flow over assets), profitability (ROA), and leverage. To avoid concerns regarding the endogeneity of controls (Angrist and Pischke, 2008; and Gormley and Matsa, 2014), these variables are measured in the pre-crisis period (2007) and then interacted with the crisis dummy to allow them to have a differential impact around the shock. These controls further alleviate concerns regarding the presence of some unbalanced observable characteristics across treatment and control groups before 2008 .

Second, as a robustness test for our main results, we also add a full set of time-varying industry fixed effects, which can account for changes in industry demand and other industry considerations around the financial crisis. In particular, we interact two-digit industry fixed effects with the post dummy. We discuss this, as well as additional robustness tests, in Section 4.2. 


\section{$4 \quad$ Investment and Funding}

\subsection{Main Results}

We start by examining whether companies backed by PE investors were more or less affected by the financial crisis. While overall investments dropped significantly in the UK during the crisis period, it is important to understand whether PE-backed companies experienced even a more severe decline during the crisis.

We start our analysis by studying the change in investment policies in PE- and non PEbacked companies. In column (1) of Table 2, we find that PE-backed companies decreased investments less than non-PE backed companies around the financial crisis. This effect is not only statistically significant, but also large in economic magnitude. Normalized by assets, the PE firms saw their investments increase almost $6 \%$ relative to the non-PE companies in the post-crisis period. In column (2), we find that the results are unchanged - in terms of both size and statistical significance-when we add the standard set of firm-level controls. ${ }^{22}$

In Figure 3, we plot the year effects estimates around the crisis - and the corresponding standard errors - separately for the PE-backed companies and matched companies. As illustrated in the figure, both treated and control firms followed similar paths before the crisis: the estimates are not statistically different from one another. Hence, the estimates seem to satisfy the parallel trends assumption. Once the crisis ensued, both the PE-backed companies and the matched companies decreased investments dramatically during 2008 and 2009. However, the PE-backed companies decreased their investments significantly less during the crisis years, consistent with the evidence in Table 1. This higher level of investment persisted in the years after the crisis.

\footnotetext{
${ }^{22}$ Since we focus on the PE treatment effects around the crisis and therefore after the PE investments, our results do not account for the potentially positive impact of the initial private equity investment on operation and financing. Since the effects of the initial investment has been generally found to be positive (e.g. Kaplan, 1989), our estimates may under-estimate the overall effect of PE on the portfolio companies.
} 
Similar conclusions arise from Column (1) of Table 3, where we estimate equation (2) to capture year-by-year PE effects (we add company controls in column (2)). This analysis formally estimates the significance of the differences between the two groups, confirming the lack of statistically significant patterns before the crisis. In contrast, note that investments by PE-backed companies substantially diverged from the control group at the same time as the sharp decline in aggregate investments and credit in the UK, as illustrated in Figures 1 and 2. This positive difference persists in the next few years. We plot the estimates in column (2) graphically in Panel A of Figure A.1 in the Appendix.

Overall, the results so far suggest that companies backed by private equity firms were more resilient in the face of the financial crisis than a similar set of non-PE backed companies, therefore contradicting the claim that PE firms increased financial fragility. Next, we move to explore the mechanism behind this finding. One hypothesis is that private equity firms help their portfolio companies to maintain high investment levels by relaxing their financial constraints, particularly during periods of financial upheaval. This can happen in two ways. First, private equity firms have fund commitments that are rarely abrogated and may therefore be in a better position to inject equity into the companies if access to financial markets is barred. Second, private equity firms have strong ties with banks (Ivashina and Kovner, 2011) and should therefore find it easier to access credit markets during periods of turmoil. We find evidence that is generally consistent with both these channels in Table 2 .

We find that net equity contributions increased more for PE-backed companies than for the control group around the crisis (Table 2, Columns 3 and 4). ${ }^{23}$ Normalized by assets, equity

\footnotetext{
${ }^{23}$ Notice that we define equity contribution by looking at the changes in equity that are not explained by profit (see Data Appendix). Therefore, we cannot distinguish whether positive effects are due to raising more capital or paying out fewer dividends.
} 
contributions during the financial crisis were $2 \%$ higher for PE-backed companies relative to nonPE firms. As illustrated in Figure 4, equity contributions for both classes of firms dropped significantly during the crisis. However, the decline was smaller for PE-backed companies. This suggests that PE funds were willing to support the operations of their portfolio companies by injecting equity into the firms. As illustrated in Columns (3) and (4) of Table 3, there are no divergent trends before the crisis. This divergence in financial policy appeared only in 2008 . We plot these estimates in the Appendix, in Panel B of Figure A.1.

At the same time, Column (5) of Table 2 illustrates that PE-backed companies also experienced a relative increase in debt issuance. ${ }^{24}$ While on average debt issuance over assets declined during the financial crisis, this decline was $4 \%$ smaller for PE-backed companies. The result is similar when adding controls, as illustrated in Column (6). These patterns can be observed in Figure 5. In the years leading to the crisis, PE-backed companies and matched companies followed similar, parallel trends. Both treated and control companies experienced a significant decline in debt issuances during the crisis. PE-backed companies, however, experienced a relative increase in debt issuance in 2008, exactly when lending conditions and aggregate investment started to decline in the UK. We find similar results when estimating equity issuances on a yearly basis in Columns (5) and (6) of Table 3. Again, we plot these estimates graphically in the Appendix, in Panel C of Figure A.1.

While overall debt issuance was greater, PE companies did not materially increase their leverage, as is evident from columns 7 and 8 in Table 2. The PE coefficient in this regression is positive, but it is non-significant and small in magnitude. This null result reflects the joint increase in equity and debt. However, in columns (9) and (10) of Table 2, we find that the relative cost of

\footnotetext{
${ }^{24}$ As discussed in the data section and in the Appendix, this is measured as the change in total debt, scaled by assets.
} 
debt, measured by the ratio of interest expense of total debt, declined for the PE-backed companies. This is also illustrated over time in Columns (7) and (8) of Table 3, confirming that the relative decline in cost of debt appears first in 2008 , the onset of the financial crisis.

One concern regarding the interpretation of the results is that by matching on leverage (in addition to other variables), we may have captured firms that are somewhat unrepresentative due to their high leverage. For this reason, we repeat the main analyses using an alternative matching that does not rely on leverage, but only on size, ROA, and industry. This matching estimator allows the two groups to have different leverage ratios in the pre-crisis period. This approach has two main advantages. First, this matching is closer to the approach of Boucly, Sraer, and Thesmar (2011). Second, using fewer matching variables allow us to match a larger number of observations.

In Table 4, we repeat the analysis with the alternative matching methodology. We find that all results remain unchanged. In Columns (1) and (2), we find as well that PE-backed companies experience a smaller decline in investment during the crisis and the effect is still highly statistically significant. Similarly, we find similar results with respect to equity contribution (Columns 3 and 4) and debt issuances (Columns 5 and 6). The only difference with our main results is a positive increase in the relative leverage ratio for PE-backed companies (Columns 7 and 8), but the effect is small in magnitude and only of borderline significance. Moreover, as is the case in the main results, we still find a decline in interest expense during the crisis for PE-backed companies.

Overall, these analyses suggest that private equity firms alleviated financing constraints of portfolio companies during the financial crisis, allowing them to invest more when credit markets were frozen and economic uncertainty high. In particular, private equity firms appear to have taken advantage of their fund structures and bank relationships to provide both equity and debt financing to their portfolio companies, with the latter at a lower cost. 


\subsection{Robustness}

In this section, we examine a set of robustness analyses. First, we drop management buyouts from the main sample. At least historically in the UK, MBOs were characterized by lower engagement of private equity firms. If their inclusion completely drove the results, the interpretation and generalization of the analysis might be subtler. To explore whether this is the case, we eliminate MBOs from the sample and repeat the main analysis. As we show in Table A.1 in the Appendix, we find similar. In columns (1) and (2), we find that the effect on investment when MBOs are dropped is even larger than the effect in our baseline model. Similarly, we confirm the expansion in equity contribution and debt issuance, the relative stability in the leverage ratio, and the decline in interest expense. Therefore, the exclusion of MBOs does not affect the results.

Second, we explore whether the main results can be driven by attrition. As usual with panel data, the endogenous exit of firms from the data may bias results. Exit may be particularly problematic if PE-backed companies are more likely to enter into distress or be targeted in M\&A transactions. To start, note first that as illustrated in Table 3, the shift in investment and financing policies occurred in 2008, immediately at the onset the financial crisis and arguably concerns about attrition may take place only later. We can also illustrate this pattern more directly by estimating our standard model using data from 2007 and 2008 only (Table A.2), in which we find similar results. In other words, much of the shift in corporate policy happened soon after the onset of the crisis.

Another alternative robustness test to revisit attrition bias concerns is to focus only on firms that did not exit the sample. In Table A.3, we take this conservative approach and drop every firm that exited the database before 2011. This approach leads to approximately $15 \%$ fewer 
observations in the sample. ${ }^{25}$ Even with this reduced sample, the main results remain unchanged. PE-backed companies appear to experience a lower decline in investment and a relative increase in equity contributions and debt issuance. At the same time, the leverage ratio stays constant, and interest expense declines.

Third, we show that our results are robust to changes in industry dynamics. One concern is that PE-backed companies may be more or less sensitive than the control group to changes in demand that are contemporaneous to the shock. In principle, this should not be a problem, because the treatment and control groups are matched across industries. Nonetheless, we augment our analysis with a full set of (two-digit) industry fixed effects interacted with the crisis dummy. This set of fixed effects can control non-parametrically for changes in demand and other time-varying industry characteristics. As we show in Table A.4 in the Appendix, despite the large number of fixed effects that the model introduces, the main results remain unchanged. The estimates are still close in magnitude and statistical power to the one presented before.

\subsection{The Heterogeneity of PE-Backed Companies}

The results so far are consistent with the idea that private equity can play an important role during financial turmoil by relaxing the financial constraints faced by their portfolio companies. In this section, we provide more evidence consistent with this hypothesis by focusing on financially constrained firms.

We use several measures as proxies for financing constraints. First, we study how the effect of PE backing on investment differs between large and small firms (Table 5, Panel A). Consistent with the idea that small companies are more likely to be financially constrained, small businesses

\footnotetext{
${ }^{25}$ For every PE-backed company, there are up to five matched control firms. There are 310 companies that exit before 2011, which corresponds to 245 groups of companies that are dropped.
} 
have been shown to be more sensitive to credit market shocks (Petersen and Rajan, 1994; Chodorow-Reich, 2014; and Bottero, Lenzu, and Mezzanotti, 2015). In our sample, we identify large firms by looking at the top quartile of employment at 2007, the last year in our pre-shock period, and classify remaining firms as small. Using this measure, we show in Columns (1) and (2) that the positive effect on investment is stronger for small companies.

Second, we find similar results when we look across companies that operate in industries that are more likely to depend on external finance, identified using the standard Rajan-Zingales (RZ) index (Rajan and Zingales, 1998). In particular, we define more financially dependent firms as companies operating in two-digit SIC industries characterized with an above-median share of capital expenditure that is externally financed. ${ }^{26}$ In principle, firms that were more dependent on external finance should have been more affected by the financial crisis, given the dramatic decline in credit availability. Therefore, if private equity provides some relief to financial stresses, companies in industries characterized by larger RZ indices should benefit more from PE. Consistent with this idea, in Columns (3) and (4) of Panel A of Table 5, we find that the positive effect of being backed by private equity is larger for firms in more financially dependent industries.

Third, we find similar results when comparing firms that were more leveraged entering into the crisis. In general, firms with higher leverage are characterized by lower financial flexibility and higher interest payment burdens. Therefore, they face more risks when credit markets dry up. Comparing companies based on their 2007 leverage levels, we define high-leverage firms if they are at the top quartile of the leverage distribution at the onset of the crisis. We find that companies with high pre-crisis leverage experienced lower investment post-crisis. But high leverage

\footnotetext{
${ }^{26}$ In line with the literature, this measure is computed using data from US corporations between 1980 and 2008, available through Compustat. In particular, for each two-digit SIC industry, we measure the RZ index as the median of CAPEX minus cash flows from operation, scaled by CAPEX.
} 
companies backed by PE investors increased investments significantly more than their non-PE counterparts (Table 5, Panel A, Columns 5 and 6). The presence of a PE investor counter-balanced the negative effect of high leverage on investments. ${ }^{27}$

Similarly, we find that the effect of PE on debt issuance seem to be stronger among financially constrained companies (Table 5, Panel B). This is true when looking across size (Columns 1 and 2) and dependence on external finance (Columns 3 and 4). When sorting by leverage (Columns 5 and 6), however, the result is positive but not statistically significant. In Panel $\mathrm{C}$ of Table 5, we explore the case of equity issuances. While the coefficients are generally in the expected direction, they are not statistically significant. This suggest that financially constrained firms particularly benefited from debt issuances to alleviate financing constraints. By way of contrast, equity contributions benefited all PE-backed companies similarly.

Overall, these results suggest that the positive effect of private equity on investments was stronger among firms that are more likely to be financially constrained. Differences in funding strategies in response to the financial crisis—-particularly with regard to debt—seem to explain this result.

\subsection{The Heterogeneity of PE Firms}

To further explore the underlying channel of the findings, we exploit heterogeneity across the private equity groups themselves. We focus on the differences in the firms in their financial and operational resources that were available by 2007 , at the onset of the financial crisis. We look at this hypothesis in two ways.

\footnotetext{
${ }^{27}$ Clearly, leverage at 2007 is endogenous to many firm characteristics, in particular debt capacity. If anything, firms that expect to respond more successfully to a negative credit shock should ex-ante employ more debt. Therefore, it is reasonable to think that the results are actually characterized by a downward bias.
} 
First, we compare PE groups based on the amount of "dry powder" that they had available. As we discuss in the data section, we have collected information from ThomsonOne about amount of capital that PE firms had raised, but not invested, in the pre-crisis period. Firms with more capital available may be better positioned to provide liquidity to their portfolio companies and may be able to commit more time and attention to portfolio companies since they deployed less capital. As discussed in the data section, we used Capital IQ and ThomsonOne to identify the PE investors in each PE-backed company. We divided the PE-backed companies in two groups, depending on whether they had PE investors that were on the top quartile of dry powder in 2007.

In Table 6, we present the results. We naturally restrict the sample to PE-backed companies only, since the variation is at investor level is therefore available only for PE-backed companies. In Columns (1) and (2), we find that firms whose PE investors had considerable amount of dry powder at the beginning of the crisis increased their investment level relatively more. The result is both statistically and economically significant: a high dry powder firm experienced a $10 \%$ increase in investment (normalized again by assets) relative to the control group. Consistent with this result, we find that this group of PE firms were also more active in financing their portfolio companies. Companies financed by high dry powder groups had 5\% greater debt issuances (Columns 5 and 6) and, importantly, 7\% larger equity injections (Columns 9 and 10), consistent with their greater availability of capital.

Second, we test this hypothesis using an alternative measure, which is whether the PE group's most recent fund was of a relatively recent vintage in 2008. This analysis is based on the underlying assumption that PE firms with younger funds have more resources available-both financial and operational - to provide to their portfolio companies. Over the course of the first three to five years of the fund, PE firms deploy capital and commit their time and attention to 
portfolio companies. Therefore, PE funds that are younger at the onset of the crisis could direct more financial and operational resources to portfolio firms. We identify the year in which these investors raised their last fund before the financial crisis. We use a dummy that equals to one if the fund was formed in the years between 2002 and $2007{ }^{28}$

In Table 6, we also find a larger increase in investment when PE investors had raised a fund more recently (Columns 3 and 4), suggesting the importance of the availability of resources for the PE group. We find similarly strong patterns with respect to debt issuances, which have increased much more for companies where the investors had raised a fund more recently (Table 6, Columns 7 and 8). The effects are both economically and statistically significant. The results for equity contributions are similarly positive and statistically significant in Column 11 . When adding firm controls in Column 12, however, while coefficients remain similar, they are no longer statistically significant.

Overall, the results in this section are consistent with the hypothesis that portfolio companies with PE investors that had more resources at the onset of the crisis, financial and operational, managed to increase investments in portfolio companies during the crisis.

\section{$5 \quad$ Performance and Company Outcomes Analysis}

\subsection{Company Performance}

In this section, we attempt to understand to what extent greater investment increased the long-term prospects of PE-backed companies. We examine this question by looking at various measures of company performance. Were the investment by PE-backed companies imprudent or

\footnotetext{
${ }^{28}$ The result is also robust when using a continuous measure of fundraising time, the year of the last fund raised before 2007 .
} 
wasteful, we would expect that these decisions would have had detrimental effects on their performance.

In Columns (1) and (2) of Panel A in Table 7, we find that PE-backed group assets grow faster than the matched firms'. This is consistent with prior findings that illustrate that PE-backed companies increased their relative investment during the crisis. Next, we turn to explore accounting measures of firm performance around the crisis period. In Columns (3) and (4), we explore EBITDA scaled by revenue, and in Columns (5) and (6), ROA, defined as net income over assets. In both cases, we do not find that PE-backed companies experienced worse performance relative to the matched firms during the crisis.

This analysis suggests that the average performance of PE-backed companies was not differentially affected by the financial shock: the increase in investment of PE-backed companies did not lead to a low quality or excessively risky projects. However, given the long-term nature of the returns in many corporate capital expenditures, these accounting measures of performance may fail to fully capture the underlying changes in asset quality and company value around the crisis. Therefore, next sections will explore two alternative dimensions of firms' performance. First, to capture the potential benefits of an increased investment, we explore how firms' market shares evolve around the crisis. Second, we examine exit patterns - both positive (M\&A acquisition) and negative (bankruptcy) — in the post-crisis period.

\subsection{Market Share}

The increase in investment may yield long-term profitability (and valuation) benefits if it allows the firm to capture a larger share of its market. We explore this hypothesis in Panel B of Table 7. For each firm in our sample, we measure its market share as the firm's sales relative to 
the total operating revenue in its industry (using the three-digit SIC codes). ${ }^{29}$ Then, using a logspecification, we explore the change in market share of PE-backed companies relative to their peers during the crisis.

In Columns (1) and (2), we explore this question focusing on market share outcomes in the first two years in the crisis (2008 and 2009), where we found the largest divergence in investment and funding policies. In other words, using market share as a dependent variable, we repeat the standard difference-in-difference model using the 2004-2009 period. We find that in the crisis period, PE-backed companies experienced an $8 \%$ increase in market share relative to the control group. In Columns (3) and (4), we show that results are also similar when we use the full sample period (2004-2011), albeit smaller and less precisely estimated. ${ }^{30}$

In order to explore what may drive this slight difference in the result, in Columns (5) and (6), we employ the fully interacted model where we examine the effect of being a PE-backed company on every year in our panel. Consistent with our previous results, we find that PE-backed companies experience a larger increase in market share in 2008 and 2009, but this effect becomes smaller and statistically non-significant in 2010 and 2011. This is consistent with the fact that the change in investment and funding policy were mostly concentrated in the 2008 and 2009, a period during which the financial turmoil and credit market freeze were most severe.

Overall, our results suggest that PE-backed companies may have channeled their investment towards an increase in market share rather than increasing their short-term profitability.

\footnotetext{
${ }^{29}$ The total operating revenue of the industry is constructed using only medium and large firms in the Orbis/Amedeus data, as previously discussed. Results are also similar using the SIC two-digit industry classification. ${ }^{30}$ In Appendix Table (A.5), we show that these results are robust to an alternative specification. In particular, rather than using the full panel, we employ only cross-sectional variation. In particular, in Columns (1) and (2), we show that PE-backed companies were more likely to have larger market share in 2009 relative to 2007 (conditional logit model). Similarly, in Columns (5) and (6), we look at the growth in market share over the same period and we find that this growth in market share was $6 \%$ higher.
} 
In the next section, we look at exit patterns as another relevant dimension to understand firms' performance.

\subsection{Exit Analysis}

In this section, we examine exit patterns in the post-crisis period. In particular, we compare the relative likelihood that PE-backed companies entered distress, went bankrupt, or were successfully acquired. This will provide an additional perspective on the performance of PEbacked companies during the crisis, potentially capturing dimensions not easily captured by accounting measures or market share.

As we discussed in the Section 2, we define "bad exits" when firm exit the sample after a status of financial distress or bankruptcy. We identify "potentially profitable exits" as company acquisitions without prior company distress. Thus, we examine how post-crisis exit patterns differed across PE-backed and non-PE companies. The variation under study is only crosssectional, as we explore the status of the sample firms in 2011. Therefore, the difference-indifference design is not suitable for these tests. To make PE and non-PE-related companies comparable in the cross-section, we control for industry fixed effects and firm characteristics. Even with these adjustments, a causal interpretation of these results requires much stronger assumptions than the previous set of results.

In particular, we estimate the following equation:

$$
\operatorname{Exit}_{i}=\alpha_{i n d(i)}+\beta\left(P E \text { firm }_{i}\right)+\gamma X_{i}^{P R E}+\varepsilon_{i t}
$$

where Exit $_{i}$ is a firm-level dummy that identifies the type of exit activity ("bad" or "potentially profitable"), $\alpha_{\text {ind(i) }}$ are industry-level fixed effects at two digit SIC level, $P E$ firm $_{i}$ is a dummy variable identifying PE-backed companies, and $X_{i}{ }^{P R E}$ are the firm-level characteristics measured 
before the crisis (2007). Since the outcome here is only cross-sectional and discrete, we estimate this model using a conditional logit model. To facilitate interpretation, all the results are presented as marginal effects at the mean.

In Panel $\mathrm{C}$ of Table 7, we show the main results. We find that PE-backed companies were more likely to experience a potentially profitable exit (Columns 1 and 4). The results are similar with and without controls, but the magnitude is a bit smaller with controls. The most conservative estimates suggest that PE-backed companies were about $30 \%$ more likely to be acquired in the post-crisis period. At the same time, PE-backed companies were not more likely to go out of business or enter into distress in the post-crisis period (columns 5-8). The results are not only insignificant, but also small in magnitude.

Overall, in the post-crisis period, PE-backed companies were more likely to be targeted in a potentially profitable M\&A transaction, and also were not more likely to go out of business. Despite the limitations of the cross-sectional analysis, the results are inconsistent with the hypothesis that PE financing increased the financial fragility of the PE-backed companies.

\section{Conclusion}

In this paper, we have studied how PE-backed companies responded to the turmoil caused by the 2008 financial crisis by exploring their investments, financing, and performance. One of the main objectives of this analysis is to explore whether PE-backed companies increased the fragility of the economy during the financial crisis, as recently articulated by the Bank of England and others. Furthermore, this analysis can improve our understanding about the relationship between economic cycles and financial intermediaries more generally. 
We find that PE-backed companies decreased investments relatively less than the control group during the financial crisis. This result can be explained by the ability of PE-backed companies to utilize the resources and relationships of their private equity sponsors to raise equity and debt funding in this difficult period, and to lower their cost of capital, as captured by the interest expense. Furthermore, we find that the positive investment effects of private equity were particularly large in companies more likely to be financially constrained at the time of the crisis and more likely to occur when PE firms have more resources. The increase in investment during the crisis led to increased asset growth, market shares, and ultimately a higher probability to be acquired. Altogether, these results are inconsistent with the hypothesis that private equity contributed to the fragility of the economy during the recent financial crisis. 


\section{References}

Angrist, J. D. and Pischke, J., Mostly Harmless Econometrics: An Empiricist's Companion. Princeton, Princeton University Press, 2008.

Axelson, U., Jenkinson, T., Strömberg, P. and Weisbach, M. S., "Borrow cheap, buy high? The determinants of leverage and pricing in buyouts.” Journal of Finance, 2013, 68, 2223-67.

Ben-David, I., Franzoni F. and Moussawi R., "Hedge fund stock trading in the financial crisis of 2007-2009." Review of Financial Studies, 2012, 25, 1-54.

Bernanke, B., "Nonmonetary effects of the financial crisis in the propagation of the Great Depression.” American Economic Review, 1983, 73, 257-275.

Bernanke, B. and Gertler, M., "Financial fragility and economic performance." Quarterly Journal of Economics, 1990, 105, 87-114.

Bernanke, B., Campbell, J., Friedman, B. and Summers, L., "Is there a corporate debt crisis?" Brookings Papers on Economic Activity, 1988, no. 1, 83-139.

Bernstein, S., Lerner, J., Sorensen, M. and Stromberg, P., "Private equity and industry performance." Management Science, 2016, forthcoming.

Bernstein, S. and Sheen, A., "The operational consequences of private equity buyouts: Evidence from the restaurant industry." Review of Financial Studies, 2016, 29, 2387-2418.

Bertrand, M., Duflo, E. and Mullainathan, S., "How much should we trust differences-indifferences estimates?” Quarterly Journal of Economics, 2004, 119, 249-275.

Blundell-Wignall, A., "The private equity boom: Causes and policy issues." Financial Market Trends: Organization for Economic Cooperation and Development, 2007, no. 92, 59-86.

Bottero, M., Lenzu, S. and Mezzanotti, F., "Sovereign debt exposure and the bank lending channel: impact on credit supply and the real economy." Bank of Italy Working Paper, 2015.

Boucly, Q., Sraer, D. and Thesmar, D., “Growth LBOs.” Journal of Financial Economics, 2011, $102,432-453$.

Brav, O., "Access to capital, capital structure, and the funding of the firm." Journal of Finance, 2009, 64, 263-308.

Chodorow-Reich, G., "The employment effects of credit market disruptions: Firm-level evidence from the 2008-9 financial crisis.” Quarterly Journal of Economics, 2014, 129, 1-59. 
Cohn, J., and Towery, E., "The determinants and consequences of private equity buyouts of private firms: Evidence from US corporate tax returns.” Working Paper, 2013.

Cumming, D., Siegel, D. and Wright, M., "Private equity, leveraged buyouts and governance." Journal of Corporate Finance, 2007, 13, 439-460.

Davis, S., Haltiwanger, J., Handley, K., Jarmin, R., Lerner, J., \& Miranda, J., "Private equity, jobs, and productivity.” American Economic Review, 2014, 104, 3956-3990.

Duchin, R., Ozbas O. and Sensoy B., "Costly external finance, corporate investment, and the subprime mortgage credit crisis." Journal of Financial Economics, 2010, 97, 418-435.

Fahlenbrach, R., Prilmeier, R. and Stulz, R. M., "This time is the same: Using bank performance in 1998 to explain bank performance during the recent financial crisis." Journal of Finance, 2012, 67, 2139-2185.

Gormley, T. A. and Matsa, D. A., "Common errors: How to (and not to) control for unobserved heterogeneity." Review of Financial Studies, 2014, 27, 617-661.

Harris, R., Siegel, D. and Wright, M., “Assessing the impact of management buyouts on economic efficiency: Plant-level evidence from the United Kingdom." Review of Economics and Statistics, 2005, 87, 148-153.

Hoshi, T., Kashyap, A. and Scharfstein, D., "The role of banks in reducing the costs of financial distress in Japan." Journal of Financial Economics, 1990, 27, 67-88.

Hoshi, T., Kashyap, A. and Scharfstein, D., "Corporate structure, liquidity, and investment: Evidence from Japanese industrial groups." Quarterly Journal of Economics, 1991, 106, $33-60$.

Hotchkiss, E., Smith, D., and Strömberg, P., "Private equity and the resolution of financial distress.” Working Paper, 2015.

Illig, R., "The Dog That Didn't Bark: Private Investment Funds and Relational Contracts in the Wake of the Great Recession.” Michigan Journal of Private Equity \& Venture Capital Law, 2012.

Ivashina, V. and Kovner, A., "The private equity advantage: Leveraged buyout firms and relationship banking." Review of Financial Studies, 2011, 24, 2462-2498.

Ivashina, V. and Scharfstein D., "Bank lending during the financial crisis of 2008." Journal of Financial Economics, 2010, 97, 319-338. 
John, K., Lang, L., and Netter, J., "The voluntary restructuring of large firms in response to performance decline,” Journal of Finance, 1992, 47, 891-917.

Kahle, K. and Stulz R., "Access to capital, investment, and the financial crisis." Journal of Financial Economics, 2013, 110, 280-299.

Kaplan, S., "The effects of management buyouts on operating performance and value." Journal of Financial Economics, 1989, 24, 217-254.

Kaplan, S. and Stein, J., "The evolution of buyout pricing and financial structure in the 1980s." Quarterly Journal of Economics, 1993, 108, 313-357.

Kaplan, S. and Stromberg, P., "Leveraged buyouts and private equity." Journal of Economic Perspectives, 2009, 23, 121-46.

Lichtenberg, F. and Siegel, D., "The effects of leveraged buyouts on productivity and related aspects of firm behavior," Journal of Financial Economics, 1990, 27, 165-194.

Michaely, R. and Roberts, M., "Corporate dividend policies: Lessons from private firms." Review of Financial Studies, 2012, 25, 711-746.

Petersen, M. and Rajan, R., "The benefits of lending relationships: Evidence from small business data." Journal of Finance, 1994, 49, 3-37.

Rajan, R. and Zingales, L., "Financial dependence and growth." American Economic Review, $1998,88,559-586$.

Reinhart, C., and Rogoff, K., This Time is Different. Princeton, Princeton University Press, 2009.

Riley, R., Rosazza Bondibene, C. and Young, G. "The financial crisis, bank lending and UK productivity: Sectoral and firm-level evidence.” National Institute Economic Review, 2014, no. 228, R17-R34. 


\section{Figure 1: Investment in United Kingdom around the financial crisis}

This figure shows the quarterly business investment volume in the United Kingdom (seasonally adjusted). Currency values are at 2013. The measure does not include expenditure on dwellings, land and existing buildings and costs of ownership transfer of non-produced assets. The data is available at the "Office of National Statistics" in the UK.(https://www.ons.gov.uk/economy/grossdomesticproductgdp/bulletins/businessinvestment/quarter3julytosept20 $\underline{16 \text { revisedresults). }}$.

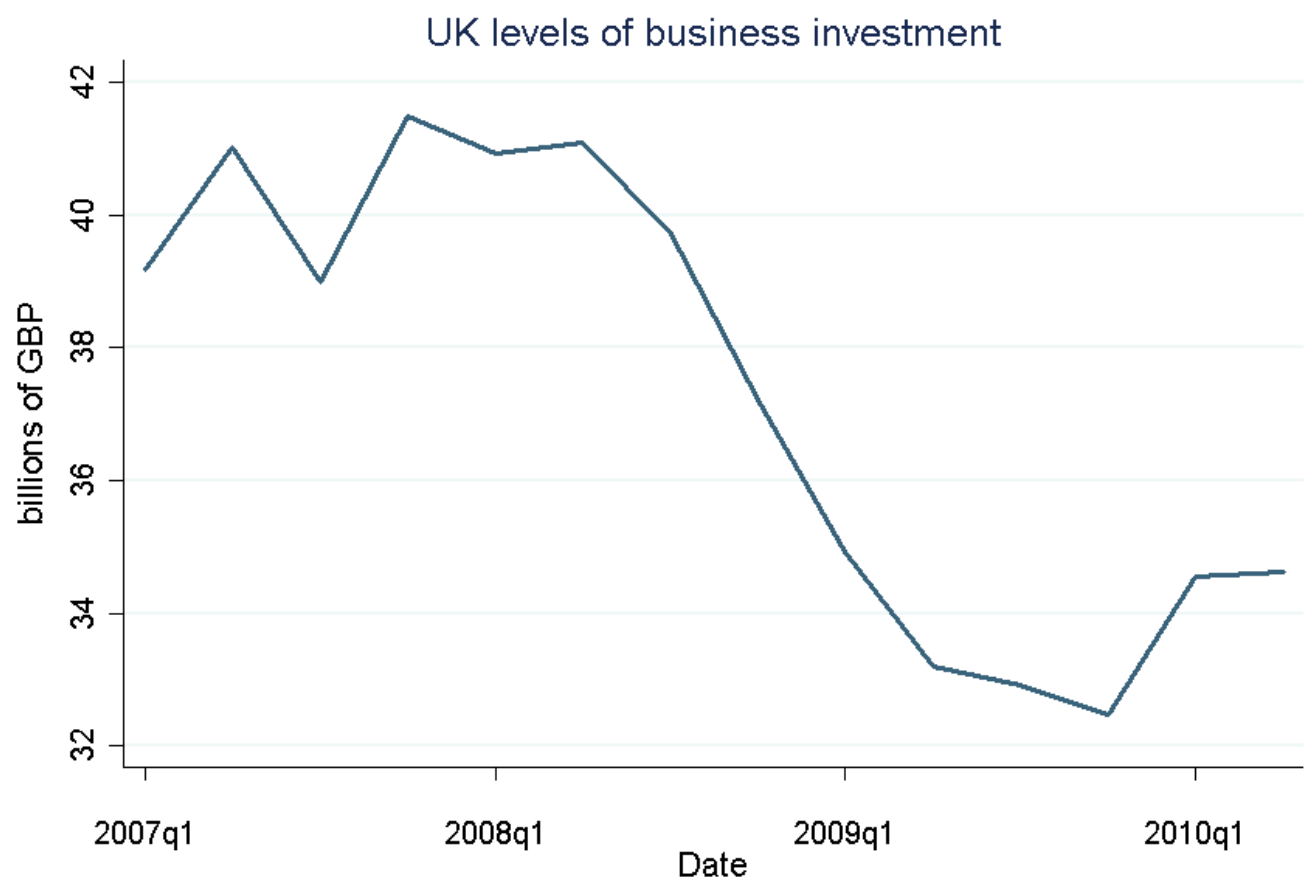

Source: UK Office for National Statistics 


\section{Figure 2: Lending growth in UK around the financial crisis}

This figure shows the growth rate in the stock of lending by UK monetary financial institutions to private non-financial corporations (PNCF) or non-financial businesses. The stock of lending is the total amount of outstanding net lending. Series included are PNFC M4Lx (seasonally adjusted), sterling loans to PNFCs (seasonally adjusted), all currency loans to PNFCs (seasonally adjusted), all currency loans to non-financial businesses (non-seasonally adjusted). PNFC M4Lx is the lending to PNFCs, which includes loans, securities, reverse repos, overdrafts, and commercial paper. The other three measures each includes loans, reverse repos and overdrafts. The data is available at the official statistics of the Bank of England and they are reported in the report "Trends in Lending (2014)." http:/www.bankofengland.co.uk/publications/Pages/other/monetary/trendsinlending2014.aspx .

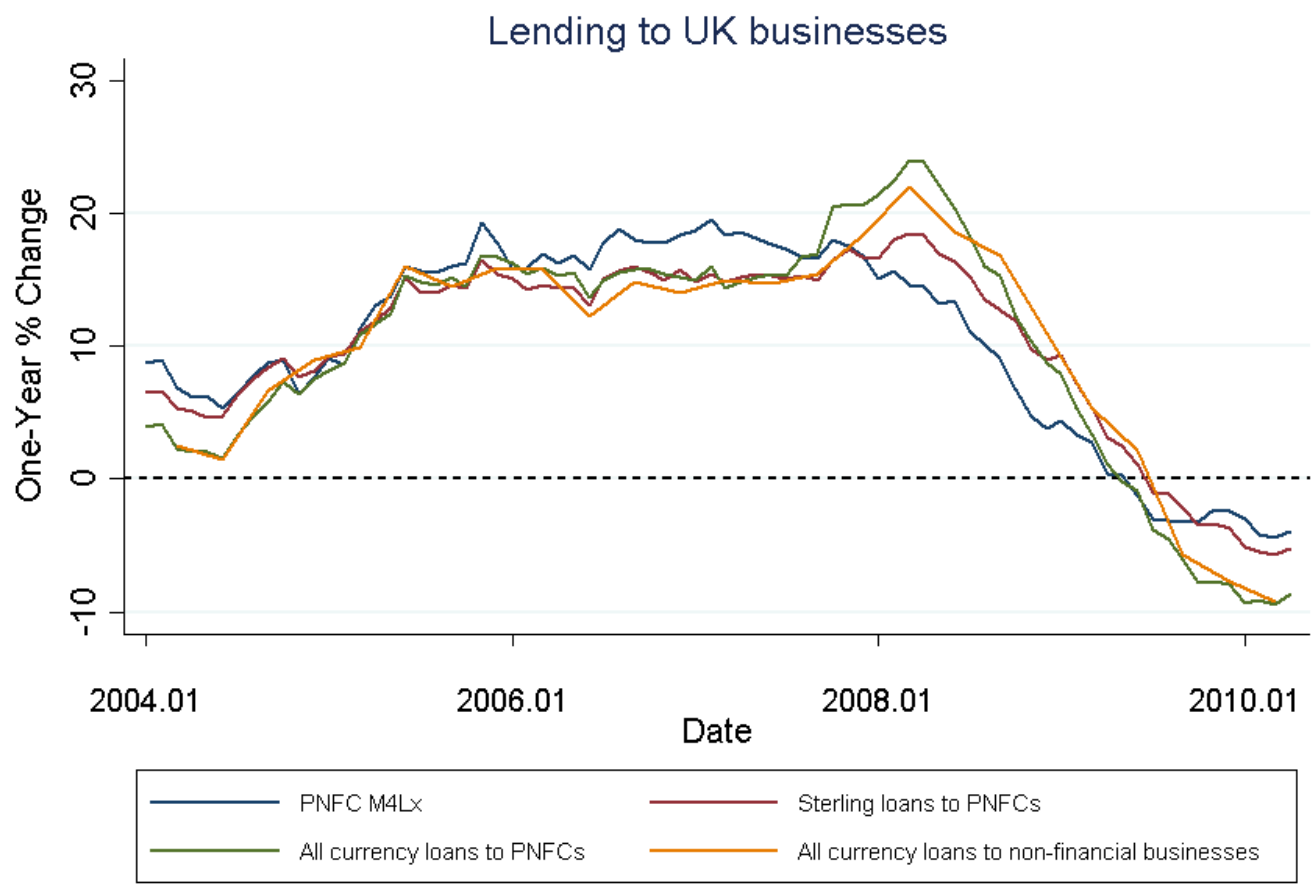

Source: Bank of England - Trends in lending 


\section{Figure 3: Effect of PE-backed companies on investment over time}

This figure illustrates the change in investment separately for both PE and non-PE companies in our sample. Specifically, the figure reports $\alpha_{t}$ of the following equation: $y_{i t}=\alpha_{t}+\alpha_{i}+\varepsilon_{i t}$, estimated separately for PE and nonPE companies, where $\alpha_{t}$ capture year fixed effects, and $\alpha_{i}$ firm fixed effects. The year 2007 is used as base period and therefore the corresponding coefficient is normalized to zero. The estimates are plotted with standard errors above and below the point estimates. Standard errors are clustered at firm-level.

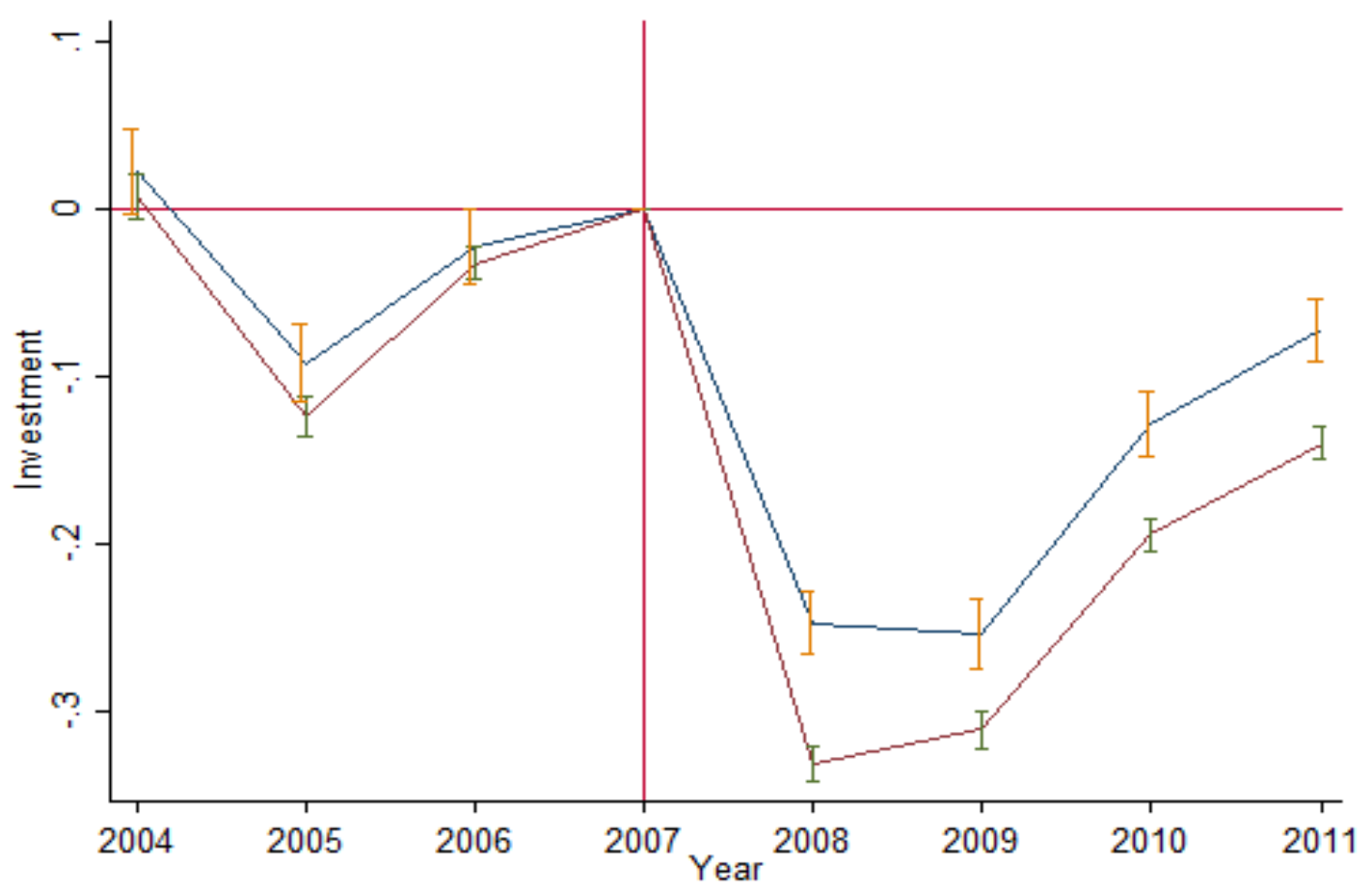




\section{Figure 4: Effect of PE-backed companies on equity contributions over time}

This figure illustrates the change in equity contributions separately for both PE and non-PE companies in our sample. Specifically, the figure reports $\alpha_{t}$ of the following equation: $y_{i t}=\alpha_{t}+\alpha_{i}+\varepsilon_{i t}$, estimated separately for PE and nonPE companies, where $\alpha_{t}$ capture year fixed effects, and $\alpha_{i}$ firm fixed effects. The year 2007 is used as base period and therefore the corresponding coefficient is normalized to zero. The estimates are plotted with standard errors above and below the point estimates. Standard errors are clustered at firm-level.

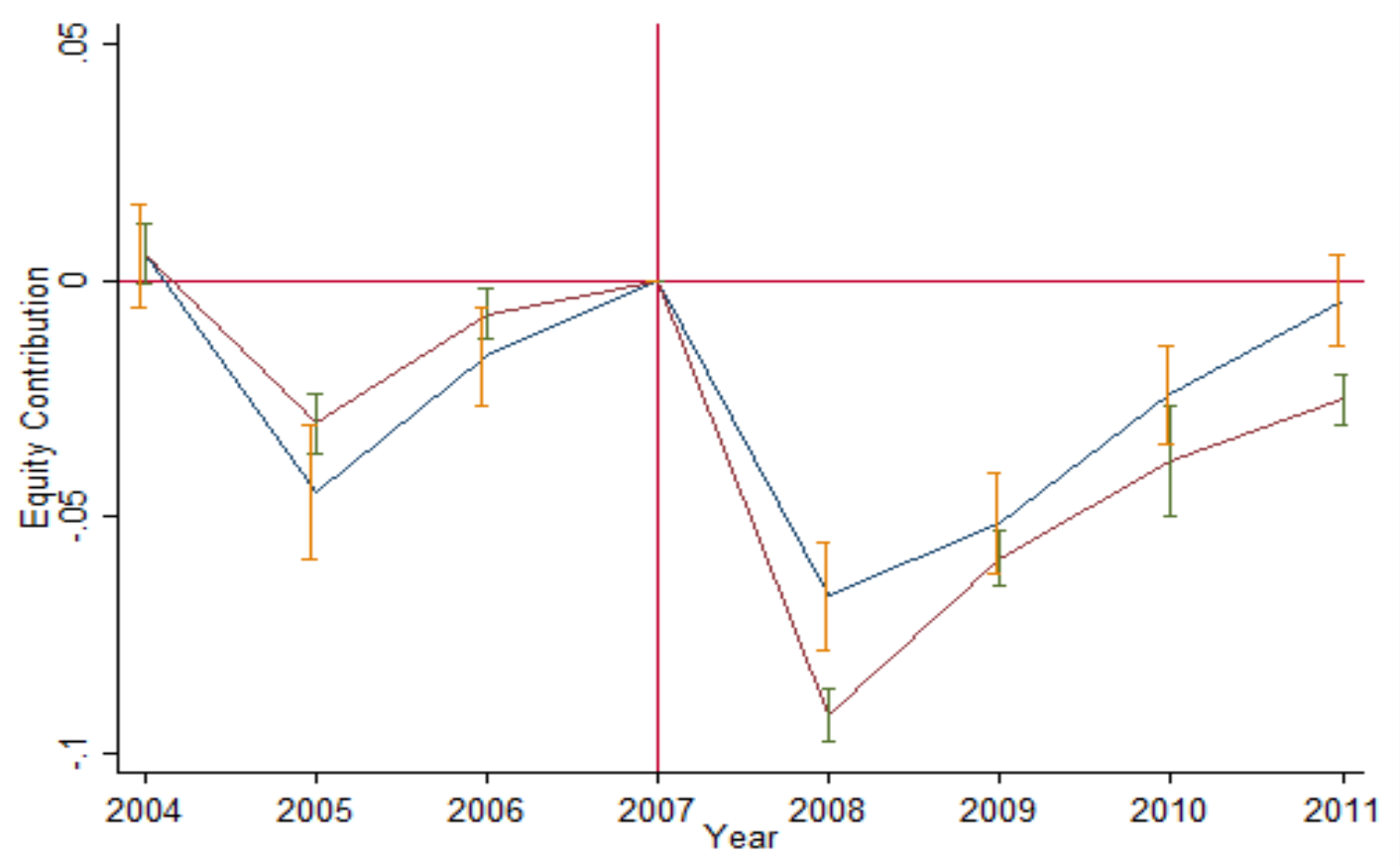




\section{Figure 5: Effect of PE-backed companies on debt issuances over time}

This figure illustrates the change in debt issuances separately for both PE and non-PE companies in our sample. Specifically, the figure reports $\alpha_{t}$ of the following equation: $y_{i t}=\alpha_{t}+\alpha_{i}+\varepsilon_{i t}$, estimated separately for PE and nonPE companies, where $\alpha_{t}$ capture year fixed effects, and $\alpha_{i}$ firm fixed effects. The year 2007 is used as base period and therefore the corresponding coefficient is normalized to zero. The estimates are plotted with standard errors above and below the point estimates. Standard errors are clustered at firm-level.

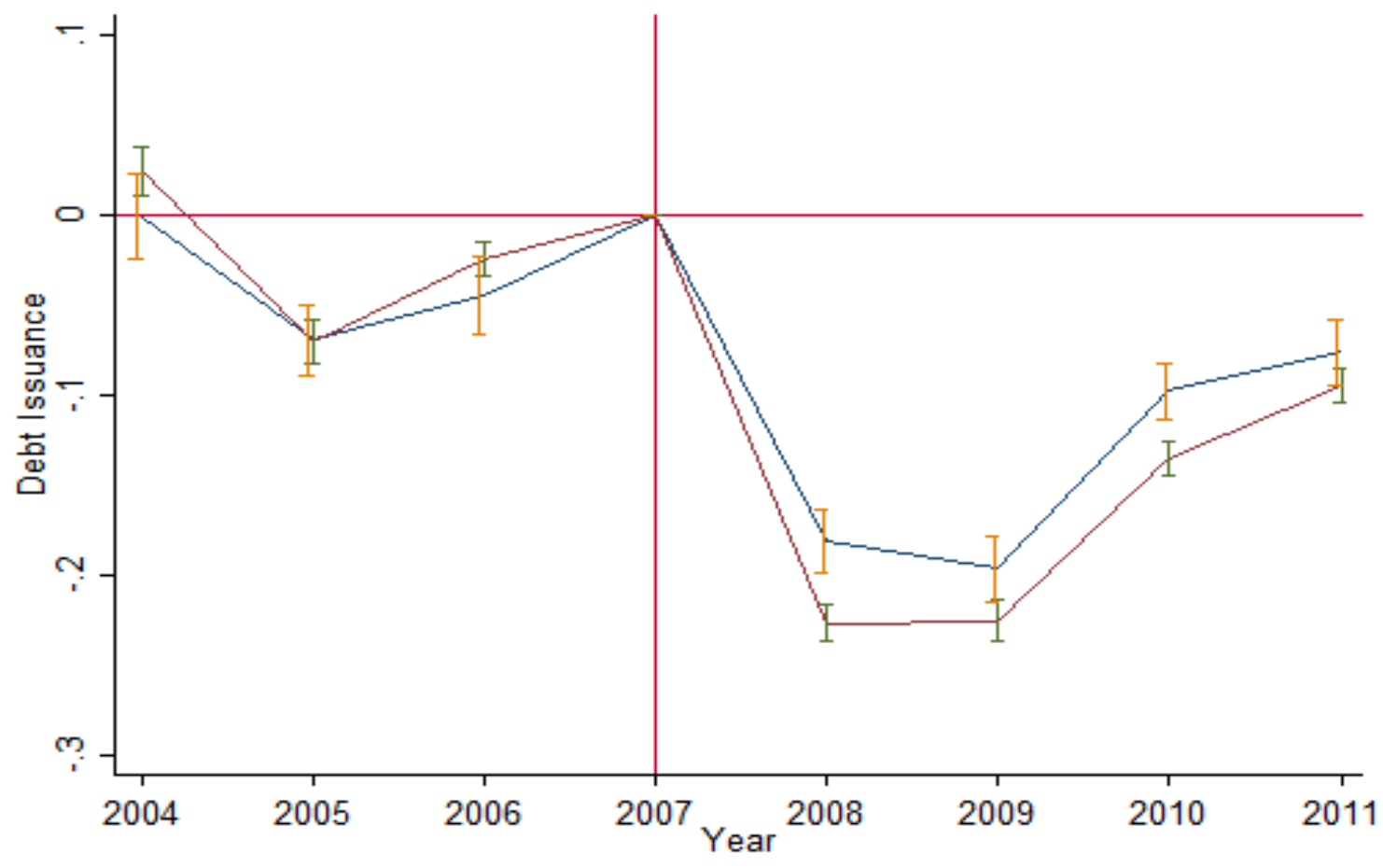




\section{Table 1: Summary Statistics}

Panel A reports the industry distribution at the macro industry level (1-digit SIC) for the PE sample and the whole universe of medium and large UK firms, but excluding financial, insurance, regulated or public administration. In Panel B reports the summary statistics of sample firms in 2007 across treated (PE-backed companies) and non-treated firms (non-PE companies). The last column reports the mean difference across the two groups. Level variables are in millions of dollars. Panel C reports the one-year and two-year growth in the characteristics in 2007. The last column reports the mean difference across the two groups. More information on variable definition is available in the Appendix. $* * *$ denotes significance at the $1 \%$ level, $* *$ at the $5 \%$, and $*$ at the $10 \%$.

\section{Panel A: Industry distribution}

\begin{tabular}{lcc}
\hline Industry Distribution & PE Sample & Full Sample \\
\hline Mining & $1 \%$ & $2 \%$ \\
Construction & $6 \%$ & $15 \%$ \\
Manufacturing & $32 \%$ & $17 \%$ \\
Wholesale Trade & $12 \%$ & $11 \%$ \\
Retail Trade & $7 \%$ & $6 \%$ \\
Transportation & $4 \%$ & $6 \%$ \\
Services & $38 \%$ & $44 \%$ \\
\hline
\end{tabular}

Panel B: Firms' characteristics in 2007

\begin{tabular}{lccccccccc}
\hline & \multicolumn{3}{c}{ PE Sample } & \multicolumn{7}{c}{ Matched Sample } \\
\cline { 2 - 10 } & $\mathrm{N}$ & Mean & Median & $\mathrm{SD}$ & $\mathrm{N}$ & Mean & Median & SD & Mean Diff. \\
\hline Revenue (M\$) & 432 & 98.05 & 35.30 & 240.81 & 1527 & 77.64 & 29.86 & 184.49 & $20.41^{*}$ \\
ROA & 434 & 0.09 & 0.09 & 0.23 & 1550 & 0.09 & 0.09 & 0.22 & 0.01 \\
Investment/Asset & 434 & 0.19 & 0.20 & 0.18 & 1550 & 0.20 & 0.20 & 0.18 & -0.01 \\
Equity Contr/Asset & 415 & -0.02 & 0.01 & 0.13 & 1513 & -0.01 & 0.01 & 0.13 & -0.01 \\
Net Debt Iss. /Asset & 415 & 0.09 & 0.10 & 0.23 & 1513 & 0.11 & 0.08 & 0.24 & -0.01 \\
Debt/Asset & 434 & 0.71 & 0.70 & 0.39 & 1550 & 0.69 & 0.67 & 0.39 & 0.02 \\
\hline
\end{tabular}


Panel C: Firms' trends in 2007

\begin{tabular}{lccccccccc}
\hline & \multicolumn{9}{c}{ PE Sample } \\
& $\mathrm{N}$ & Mean & Median & SD & N & Mean & Median & SD & Mean Diff. \\
\hline One Year Growth & & & & & & & & & \\
\hline Revenue & 423 & 0.37 & 0.18 & 1.34 & 1456 & 0.35 & 0.17 & 1.17 & 0.02 \\
ROA & 427 & 0.71 & -0.03 & 5.21 & 1483 & 0.79 & 0.07 & 4.48 & -0.07 \\
Investment/Asset & 386 & 1.54 & 0.10 & 5.86 & 1434 & 1.37 & 0.05 & 5.20 & 0.17 \\
Equity Contr/Asset & 372 & -0.59 & 0.39 & 15.96 & 1376 & -0.93 & 0.09 & 13.73 & 0.34 \\
Net Debt Iss. /Asset & 376 & 2.95 & 0.32 & 15.09 & 1428 & 2.25 & 0.20 & 12.86 & 0.70 \\
Debt/Asset & 418 & 0.02 & -0.03 & 0.34 & 1516 & 0.02 & -0.02 & 0.31 & 0.01 \\
\hline Two Year Growth & & & & & & & & & \\
\hline Revenue & 393 & 0.56 & 0.33 & 2.08 & 1362 & 0.71 & 0.34 & 2.33 & -0.15 \\
ROA & 400 & 1.10 & 0.05 & 8.33 & 1388 & 1.40 & 0.11 & 6.97 & -0.29 \\
Investment/Asset & 339 & 1.85 & 0.61 & 6.22 & 1333 & 2.39 & 0.94 & 6.06 & -0.54 \\
Equity Contr/Asset & 330 & 0.43 & 1.09 & 23.44 & 1274 & 0.70 & 1.05 & 18.95 & -0.28 \\
Net Debt Iss. /Asset & 343 & 3.45 & 0.65 & 18.73 & 1359 & 2.94 & 0.76 & 13.99 & 0.51 \\
Debt/Asset & 382 & 0.01 & -0.04 & 0.46 & 1442 & 0.04 & -0.04 & 0.60 & -0.03 \\
\hline
\end{tabular}




\section{Table 2: Investment and funding policies}

This table reports the estimates of a difference-in-difference fixed effect model on the investment and funding variables. All specifications include firm and year fixed effects. The main parameter of interest is the interaction between the crisis dummy and PE-backed company dummy variable. Odd columns contain the baseline regression and even columns augment the baseline model with a set of firm level controls measured before the crisis and interacted with the post dummy. These variables include firm size (log of revenue), growth in revenue, cash flow over assets, ROA, and leverage. In Columns (1) and (2) the outcome is investment scaled by assets; in Columns (3) and (4) is net equity contribution over assets; in Columns (5) and (6) is the net debt issuance scaled by assets; in Columns (7) and (8) is the total leverage; in Columns (9) and (10) on average interest rate. More information on the variables are available in the Appendix. Standard errors are clustered at firm level. *** denotes significance at the $1 \%$ level, ** at the $5 \%$, and * at the $10 \%$.

\begin{tabular}{|c|c|c|c|c|c|c|c|c|c|c|}
\hline \multirow{2}{*}{\multicolumn{3}{|c|}{$\begin{array}{cc}(1) & (2) \\
\text { Investment/Assets }\end{array}$}} & \multirow{2}{*}{\multicolumn{2}{|c|}{$\begin{array}{c}\text { (3) } \\
\text { Net Equity Contr./Assets }\end{array}$}} & \multirow{2}{*}{\multicolumn{2}{|c|}{$\begin{array}{c}(5) \\
\text { Net Debt Iss./Assets }\end{array}$}} & \multirow{2}{*}{\multicolumn{2}{|c|}{ Leverage }} & (9) & $(10)$ \\
\hline & & & & & & & & & \multicolumn{2}{|c|}{ Interest Rate } \\
\hline PE firm $x$ Crisis & $\begin{array}{c}0.059 * * * \\
(0.013)\end{array}$ & $\begin{array}{c}0.056 * * * \\
(0.013)\end{array}$ & $\begin{array}{c}0.022 * * * \\
(0.007)\end{array}$ & $\begin{array}{c}0.021 * * * \\
(0.007)\end{array}$ & $\begin{array}{c}0.042 * * * \\
(0.011)\end{array}$ & $\begin{array}{c}0.039 * * * \\
(0.011)\end{array}$ & $\begin{array}{c}0.013 \\
(0.015)\end{array}$ & $\begin{array}{c}0.012 \\
(0.014)\end{array}$ & $\begin{array}{c}-0.003 * * \\
(0.001)\end{array}$ & $\begin{array}{c}-0.003 * * \\
(0.001)\end{array}$ \\
\hline Year Fixed Effects & Yes & Yes & Yes & Yes & Yes & Yes & Yes & Yes & Yes & Yes \\
\hline Firm Fixed Effects & Yes & Yes & Yes & Yes & Yes & Yes & Yes & Yes & Yes & Yes \\
\hline Firm Control & No & Yes & No & Yes & No & Yes & No & Yes & No & Yes \\
\hline Observations & 12456 & 11910 & 12469 & 12003 & 12903 & 12274 & 13205 & 12553 & 10222 & 9831 \\
\hline Clusters & 1984 & 1878 & 1981 & 1876 & 1982 & 1876 & 1984 & 1878 & 1841 & 1743 \\
\hline R-squared & 0.160 & 0.161 & 0.040 & 0.059 & 0.090 & 0.104 & 0.011 & 0.029 & 0.016 & 0.022 \\
\hline
\end{tabular}




\section{Table 3: Investment and funding policies over time}

This table reports the estimates from a time-varying fixed effects model. All specifications include firm and year fixed effects. Specifically, the table reports $\beta_{t}$ of the following equation: $y_{i t}=\alpha_{t}+\alpha_{i}+\beta_{t}\left(P E\right.$ firm $\left._{i}\right)+\varepsilon_{i t}$ where $\alpha_{t}$ capture year fixed effects, and $\alpha_{i}$ firm fixed effects. E columns augment the baseline model with a set of firm level controls measured before the crisis and interacted with the post dummy. These variables are firm size $(\log$ of revenue), growth in revenue, cash flow over assets, ROA, and leverage. In Columns (1) and (2) the outcome is investment scaled by assets; in Columns (3) and (4) the outcome is net equity contribution over assets; in Columns (5) and (6) is the net debt issuance over assets; in Columns (7) and (8) is average interest rate. More information on the variables is available in the Appendix. Standard errors are clustered at firm level. *** denotes significance at the $1 \%$ level, ${ }^{* *}$ at the $5 \%$, and $*$ at the $10 \%$.

\begin{tabular}{|c|c|c|c|c|c|c|c|c|}
\hline & (1) & (2) & (3) & (4) & $(5)$ & (6) & (7) & (8) \\
\hline \multicolumn{9}{|c|}{ Net Equity } \\
\hline PE firm x y2004 & $\begin{array}{c}0.015 \\
(0.029)\end{array}$ & $\begin{array}{c}0.018 \\
(0.029)\end{array}$ & $\begin{array}{l}-0.000 \\
(0.013)\end{array}$ & $\begin{array}{c}0.002 \\
(0.013)\end{array}$ & $\begin{array}{l}-0.026 \\
(0.027)\end{array}$ & $\begin{array}{l}-0.028 \\
(0.028)\end{array}$ & $\begin{array}{c}0.001 \\
(0.003)\end{array}$ & $\begin{array}{l}-0.000 \\
(0.003)\end{array}$ \\
\hline PE firm x y2005 & $\begin{array}{c}0.032 \\
(0.026)\end{array}$ & $\begin{array}{c}0.032 \\
(0.026)\end{array}$ & $\begin{array}{l}-0.015 \\
(0.015)\end{array}$ & $\begin{array}{l}-0.013 \\
(0.016)\end{array}$ & $\begin{array}{c}0.001 \\
(0.023)\end{array}$ & $\begin{array}{c}0.000 \\
(0.023)\end{array}$ & $\begin{array}{l}-0.002 \\
(0.002)\end{array}$ & $\begin{array}{l}-0.002 \\
(0.002)\end{array}$ \\
\hline PE firm x y2006 & $\begin{array}{c}0.010 \\
(0.024)\end{array}$ & $\begin{array}{c}0.009 \\
(0.025)\end{array}$ & $\begin{array}{l}-0.009 \\
(0.012)\end{array}$ & $\begin{array}{l}-0.010 \\
(0.012)\end{array}$ & $\begin{array}{l}-0.020 \\
(0.024)\end{array}$ & $\begin{array}{l}-0.024 \\
(0.024)\end{array}$ & $\begin{array}{c}0.002 \\
(0.002)\end{array}$ & $\begin{array}{c}0.002 \\
(0.002)\end{array}$ \\
\hline PE firm x y2008 & $\begin{array}{c}0.084 * * * \\
(0.022)\end{array}$ & $\begin{array}{c}0.087 * * * \\
(0.022)\end{array}$ & $\begin{array}{c}0.025 * * \\
(0.013)\end{array}$ & $\begin{array}{c}0.025^{* *} \\
(0.012)\end{array}$ & $\begin{array}{c}0.046^{* *} \\
(0.021)\end{array}$ & $\begin{array}{c}0.043 * * \\
(0.020)\end{array}$ & $\begin{array}{c}-0.003 * * \\
(0.001)\end{array}$ & $\begin{array}{c}-0.003 * * \\
(0.001)\end{array}$ \\
\hline PE firm x y2009 & $\begin{array}{c}0.057 * * \\
(0.024)\end{array}$ & $\begin{array}{l}0.050 * * \\
(0.024)\end{array}$ & $\begin{array}{c}0.008 \\
(0.012)\end{array}$ & $\begin{array}{c}0.006 \\
(0.012)\end{array}$ & $\begin{array}{c}0.029 \\
(0.021)\end{array}$ & $\begin{array}{c}0.022 \\
(0.021)\end{array}$ & $\begin{array}{l}-0.002 \\
(0.002)\end{array}$ & $\begin{array}{l}-0.002 \\
(0.002)\end{array}$ \\
\hline PE firm x y2010 & $\begin{array}{c}0.067 * * * \\
(0.021)\end{array}$ & $\begin{array}{c}0.064 * * * \\
(0.021)\end{array}$ & $\begin{array}{c}0.014 \\
(0.012)\end{array}$ & $\begin{array}{c}0.013 \\
(0.012)\end{array}$ & $\begin{array}{l}0.037^{* *} \\
(0.018)\end{array}$ & $\begin{array}{l}0.032 * \\
(0.018)\end{array}$ & $\begin{array}{l}-0.003 * \\
(0.002)\end{array}$ & $\begin{array}{c}-0.004 * * \\
(0.002)\end{array}$ \\
\hline PE firm x y2011 & $\begin{array}{c}0.068 * * * \\
(0.021)\end{array}$ & $\begin{array}{c}0.064 * * * \\
(0.021)\end{array}$ & $\begin{array}{l}0.021 * \\
(0.011)\end{array}$ & $\begin{array}{l}0.018 * \\
(0.011)\end{array}$ & $\begin{array}{c}0.019 \\
(0.020)\end{array}$ & $\begin{array}{c}0.019 \\
(0.020)\end{array}$ & $\begin{array}{l}-0.002 \\
(0.002)\end{array}$ & $\begin{array}{l}-0.003 \\
(0.002)\end{array}$ \\
\hline Year Fixed Effects & Yes & Yes & Yes & Yes & Yes & Yes & Yes & Yes \\
\hline Firm Fixed Effects & Yes & Yes & Yes & Yes & Yes & Yes & Yes & Yes \\
\hline Firm Control & No & Yes & No & Yes & No & Yes & No & Yes \\
\hline Observations & 12456 & 11910 & 12469 & 12003 & 12903 & 12274 & 10222 & 9831 \\
\hline Clusters & 1984 & 1878 & 1981 & 1876 & 1982 & 1876 & 1841 & 1743 \\
\hline R-squared & 0.160 & 0.161 & 0.040 & 0.059 & 0.090 & 0.104 & 0.016 & 0.021 \\
\hline
\end{tabular}




\section{Table 4: Main results with alternative matching sample}

This table reports the estimates of a difference-in-difference fixed effect model on the investment and funding variables using an alternative matching estimator based only on ROA, industry and size. All specifications include firm and year fixed effects. The main parameter of interest is the interaction between the crisis dummy and PE-backed company dummy variable. Odd columns contain the baseline regression and even columns augment the baseline model with a set of firm level controls measured before the crisis and interacted with the post dummy. These variables include firm size (log of revenue), growth in revenue, cash flow over assets, ROA, and leverage. In Columns (1) and (2) the outcome is investment scaled by assets; in Columns (3) and (4) is net equity contribution over assets; in Columns (5) and (6) is the net debt issuance scaled by assets; in Columns (7) and (8) is the total leverage; in Columns (9) and (10) on average interest rate. More information on the variables are available in the Appendix. Standard errors are clustered at firm level. *** denotes significance at the $1 \%$ level, $* *$ at the $5 \%$, and $*$ at the $10 \%$.

\begin{tabular}{|c|c|c|c|c|c|c|c|c|c|c|}
\hline & (1) & $(2)$ & (3) & (4) & $(5)$ & $(6)$ & (7) & (8) & $(9)$ & $(10)$ \\
\hline & \multicolumn{2}{|c|}{ Investment/Assets } & \multicolumn{2}{|c|}{ Net Equity Contr./Assets } & \multicolumn{2}{|c|}{ Net Debt Iss./Assets } & \multicolumn{2}{|c|}{ Leverage } & \multicolumn{2}{|c|}{ Interest Rate } \\
\hline PE firm $x$ Crisis & $\begin{array}{c}0.057 * * * \\
(0.012)\end{array}$ & $\begin{array}{c}0.053 * * * \\
(0.012)\end{array}$ & $\begin{array}{c}0.025 * * * \\
(0.007)\end{array}$ & $\begin{array}{c}0.022 * * * \\
(0.007)\end{array}$ & $\begin{array}{c}0.040 * * * \\
(0.011)\end{array}$ & $\begin{array}{c}0.037 * * * \\
(0.011)\end{array}$ & $\begin{array}{l}0.026^{*} \\
(0.015)\end{array}$ & $\begin{array}{l}0.024 * \\
(0.015)\end{array}$ & $\begin{array}{l}-0.003 * * * \\
(0.001)\end{array}$ & $\begin{array}{l}-0.004 * * * \\
(0.001)\end{array}$ \\
\hline Year Fixed Effects & Yes & Yes & Yes & Yes & Yes & Yes & Yes & Yes & Yes & Yes \\
\hline Firm Fixed Effects & Yes & Yes & Yes & Yes & Yes & Yes & Yes & Yes & Yes & Yes \\
\hline Firm Control & No & Yes & No & Yes & No & Yes & No & Yes & No & Yes \\
\hline Observations & 16318 & 15672 & 16347 & 15790 & 16872 & 16150 & 17259 & 16512 & 12808 & 12369 \\
\hline $\begin{array}{l}\text { Clusters } \\
\text { R-squared }\end{array}$ & $\begin{array}{l}2598 \\
0.153\end{array}$ & $\begin{array}{l}2477 \\
0.153\end{array}$ & $\begin{array}{l}2596 \\
0.040\end{array}$ & $\begin{array}{l}2475 \\
0.076\end{array}$ & $\begin{array}{l}2596 \\
0.075\end{array}$ & $\begin{array}{l}2475 \\
0.103\end{array}$ & $\begin{array}{l}2598 \\
0.009\end{array}$ & $\begin{array}{l}2477 \\
0.026\end{array}$ & $\begin{array}{l}2356 \\
0.011\end{array}$ & $\begin{array}{l}2251 \\
0.015\end{array}$ \\
\hline
\end{tabular}




\section{Table 5: Heterogeneity across firms' financial constraints}

These tables estimate standard difference-in-difference fixed effect model and repeat the specification of Table 2 while exploring various proxies of financing constraints in 2007. All specifications include firm and year fixed effects. In each table, the interaction term in Columns 1 and 2 is based on firm size, and equal one if the firm is at the top quartile of firm employment versus the rest of the sample. The interaction in Columns 3 and 4 is based on dependency on external finance, measured by RZ index (Rajan and Zingales, 1998). The interaction equals one if dependence on external finance is above the median, and zero otherwise. In Columns 5 and 6 , the interaction is based on firm leverage. The interaction equals one if firm leverage is at the top quartile within the sample. Panel A reports the results using investment as an outcome, Panel B uses instead debt issuance over assets as dependent variable and lastly Panel C reports the results with net equity contributions over assets. Even columns augment the baseline model with a set of firm level controls measured before the crisis and interacted with the post dummy. These variables are firm size (log of revenue), growth in revenue, cash flow over assets, ROA, and leverage. More information on the variables are available in the Appendix. Standard errors are clustered at firm level. *** denotes significance at the $1 \%$ level, $* *$ at the $5 \%$, and $*$ at the $10 \%$.

Panel A - Investment / Assets

\begin{tabular}{|c|c|c|c|c|c|c|}
\hline & $(1)$ & $(2)$ & (3) & (4) & $(5)$ & $(6)$ \\
\hline PE firm $x$ Crisis & $\begin{array}{c}0.014 \\
(0.020)\end{array}$ & $\begin{array}{c}0.011 \\
(0.020)\end{array}$ & $\begin{array}{c}0.030 * * \\
(0.014)\end{array}$ & $\begin{array}{c}0.023 \\
(0.014)\end{array}$ & $\begin{array}{c}0.023 \\
(0.017)\end{array}$ & $\begin{array}{c}0.023 \\
(0.018)\end{array}$ \\
\hline Interaction $\mathrm{x}$ Crisis & $\begin{array}{l}-0.025^{*} \\
(0.013)\end{array}$ & $\begin{array}{l}-0.016 \\
(0.015)\end{array}$ & $\begin{array}{c}-0.047 * * * \\
(0.012)\end{array}$ & $\begin{array}{c}-0.041 * * * \\
(0.012)\end{array}$ & $\begin{array}{c}-0.055^{* * *} \\
(0.012)\end{array}$ & $\begin{array}{c}-0.038 * * * \\
(0.014)\end{array}$ \\
\hline Interaction $\mathrm{x}$ Crisis $\mathrm{x} \mathrm{PE}$ & $\begin{array}{c}0.053 * * \\
(0.026)\end{array}$ & $\begin{array}{c}0.051 * * \\
(0.026)\end{array}$ & $\begin{array}{c}0.067 * * \\
(0.027)\end{array}$ & $\begin{array}{c}0.077 * * * \\
(0.026)\end{array}$ & $\begin{array}{c}0.072 * * * \\
(0.025)\end{array}$ & $\begin{array}{c}0.064 * * * \\
(0.025)\end{array}$ \\
\hline Interaction Variable & \multicolumn{2}{|c|}{ Small } & $\begin{array}{c}\text { External } \\
\text { Dependence }\end{array}$ & & \multicolumn{2}{|c|}{ High Leverage } \\
\hline Year Fixed Effects & Yes & Yes & Yes & Yes & Yes & Yes \\
\hline Firm Fixed Effects & Yes & Yes & No & Yes & Yes & Yes \\
\hline Firm Control & No & Yes & No & Yes & No & Yes \\
\hline Observations & 11539 & 11105 & 12456 & 11910 & 12456 & 11910 \\
\hline Clusters & 1824 & 1742 & 1984 & 1878 & 1984 & 1878 \\
\hline R-squared & 0.160 & 0.162 & 0.161 & 0.162 & 0.162 & 0.162 \\
\hline
\end{tabular}


Panel B - New Debt Issuances / Assets

\begin{tabular}{|c|c|c|c|c|c|c|}
\hline & $(1)$ & (2) & (3) & (4) & $(5)$ & $(6)$ \\
\hline PE firm $x$ Crisis & $\begin{array}{l}-0.004 \\
(0.019)\end{array}$ & $\begin{array}{c}0.003 \\
(0.019)\end{array}$ & $\begin{array}{c}0.014 \\
(0.013)\end{array}$ & $\begin{array}{c}0.012 \\
(0.012)\end{array}$ & $\begin{array}{c}0.036^{* * *} \\
(0.013)\end{array}$ & $\begin{array}{c}0.033^{* *} \\
(0.013)\end{array}$ \\
\hline Interaction $\mathrm{x}$ Crisis & $\begin{array}{l}-0.015 \\
(0.014)\end{array}$ & $\begin{array}{c}-0.030^{* *} \\
(0.014)\end{array}$ & $\begin{array}{c}-0.049^{* * *} \\
(0.012)\end{array}$ & $\begin{array}{c}-0.035^{* * *} \\
(0.011)\end{array}$ & $\begin{array}{c}-0.152^{* * *} \\
(0.011)\end{array}$ & $\begin{array}{c}-0.096^{* * *} \\
(0.013)\end{array}$ \\
\hline Interaction $\mathrm{x}$ Crisis $\mathrm{x} P \mathrm{PE}$ & $\begin{array}{c}0.055^{* *} \\
(0.024)\end{array}$ & $\begin{array}{l}0.046^{*} \\
(0.024)\end{array}$ & $\begin{array}{c}0.062 * * * \\
(0.024)\end{array}$ & $\begin{array}{c}0.062 * * * \\
(0.024)\end{array}$ & $\begin{array}{c}0.028 \\
(0.021)\end{array}$ & $\begin{array}{c}0.023 \\
(0.021)\end{array}$ \\
\hline Interaction Variable & \multicolumn{2}{|c|}{ Small } & $\begin{array}{c}\text { External } \\
\text { Dependence }\end{array}$ & & \multicolumn{2}{|c|}{ High Leverage } \\
\hline Year Fixed Effects & Yes & Yes & Yes & Yes & Yes & Yes \\
\hline Firm Fixed Effects & Yes & Yes & No & Yes & Yes & Yes \\
\hline Firm Control & No & Yes & No & Yes & No & Yes \\
\hline Observations & 11891 & 11400 & 12903 & 12274 & 12903 & 12274 \\
\hline Clusters & 1823 & 1741 & 1982 & 1876 & 1982 & 1876 \\
\hline R-squared & 0.089 & 0.101 & 0.091 & 0.105 & 0.105 & 0.109 \\
\hline
\end{tabular}

Panel C - Net Equity Contr./Assets

\begin{tabular}{lcccccc}
\hline & $(1)$ & $(2)$ & $(3)$ & $(4)$ & $(5)$ & $(6)$ \\
\hline & & & & & & \\
PE firm x Crisis & $0.035^{* * *}$ & $0.026^{* *}$ & $0.016^{*}$ & 0.013 & 0.011 & 0.013 \\
& $(0.012)$ & $(0.012)$ & $(0.009)$ & $(0.009)$ & $(0.012)$ & $(0.012)$ \\
& & & & & & \\
Interaction x Crisis & -0.006 & 0.014 & 0.002 & -0.002 & $0.067^{* * *}$ & $0.044^{* * *}$ \\
& $(0.007)$ & $(0.008)$ & $(0.007)$ & $(0.006)$ & $(0.006)$ & $(0.006)$ \\
& & & & & & \\
Interaction x Crisis x PE & -0.016 & -0.008 & 0.015 & 0.016 & 0.011 & 0.009 \\
& $(0.016)$ & $(0.015)$ & $(0.015)$ & $(0.014)$ & $(0.015)$ & $(0.014)$ \\
& & & & & & \\
& & & External & & & High Leverage \\
Interaction Variable & Small & Dependence & & Yes & Yes \\
Year Fixed Effects & Yes & Yes & Yes & Yes & Yes & Yes \\
Firm Fixed Effects & Yes & Yes & No & Yes & No & Yes \\
Firm Control & No & Yes & No & 11989 & 12469 & 11989 \\
Observations & 11564 & 11183 & 12469 & 1873 & 1981 & 1873 \\
Clusters & 1823 & 1739 & 1981 & 0.059 & 0.053 & 0.064 \\
R-squared & 0.045 & 0.063 & 0.040 & 0.059 \\
\hline
\end{tabular}




\section{Table 6: Heterogeneity across funds}

This table reports the estimates from a difference-in-difference fixed effect model, while exploring heterogeneity across resource availability of PE firms backing the company. The analysis is a cross-section estimated using only the set of PE-backed companies. High Dry Powder is a dummy variable equals to one if PE investors are at the top quartile for amount of dry powder at 2007, defined based on the amount of capital raised but not invested. The variable 1(Fund 02-07) is a dummy variable equals to one if the PE firm raised its latest fund between 2002 and 2007 . All specifications contain firm and year fixed effects. Even columns augment the baseline model with a set of firm level controls measured before the crisis and interacted with the post dummy. These variables are firm size (log of revenue), growth in revenue, cash flow over assets, ROA, and leverage. More information on the variables are available in the Appendix. Standard errors are clustered at firm level. $* * *$ denotes significance at the $1 \%$ level, $* *$ at the $5 \%$, and $*$ at the $10 \%$.

(1)

(2)

(4)

(5)

(6)

(8)

(9)

(10)

$(11)$

Investment/Assets

Net Debt Iss./Assets

Net Equity Contr./Assets

\begin{tabular}{|c|c|c|c|c|c|}
\hline \multirow[t]{2}{*}{ Post*High Dry Powder } & $0.105 * *$ & $0.086 * *$ & $0.053 *$ & $0.062 * *$ & $0.070 * * *$ \\
\hline & $(0.048)$ & $(0.041)$ & $(0.031)$ & $(0.03)$ & $(0.025)$ \\
\hline
\end{tabular}

Post*1(Fund 02-07)

$0.075 * \quad 0.090 * *$

$0.064 * * \quad 0.073 * * *$

$0.036^{*}$

0.030

$(0.039) \quad(0.036)$

$(0.026) \quad(0.026)$

(0.021) (0.021)

\begin{tabular}{|c|c|c|c|c|c|c|c|c|c|c|c|c|}
\hline Year Fixed Effects & Yes & Yes & Yes & Yes & Yes & Yes & Yes & Yes & Yes & Yes & Yes & Yes \\
\hline Firm Fixed Effects & Yes & Yes & Yes & Yes & Yes & Yes & Yes & Yes & Yes & Yes & Yes & Yes \\
\hline Firm Control & No & Yes & No & Yes & No & Yes & No & Yes & No & Yes & No & Yes \\
\hline Observations & 1582 & 1539 & 1582 & 1539 & 1589 & 1546 & 1589 & 1546 & 1565 & 1527 & 1565 & 1527 \\
\hline Adjusted R-squared & 0.108 & 0.117 & 0.106 & 0.117 & 0.064 & 0.068 & 0.064 & 0.068 & 0.028 & 0.048 & 0.023 & 0.044 \\
\hline
\end{tabular}




\section{Table 7: Performance Analysis}

Panel A reports a standard difference-in-difference fixed effect model exploring various performance measures. All specifications include firm and year fixed effects. In Columns (1) and (2) the outcome is one year assets growth; in Columns (3) and (4) is total EBITDA scaled by revenue; in Columns (5) and (6) is ROA. Standard errors are clustered at firm level. In Panel B, the dependent variable is firm market share, measured as the log of share of firms' revenue scaled by total revenue at the level of three-digit SIC industry. Columns (1) and (2) estimate the standard model, but using only data from 2004-2009. Columns (3) and (4) instead uses the full sample period of 2004-2011. Lastly, Columns (5) and (6) report the coefficient from the time-varying regression. Standard errors are clustered at firmlevel. In Panel C, we report the marginal value (at the mean) of a conditional logit model where we study the effect of being a PE-backed company on various exit outcomes. Even columns have firm level controls at 2007. In Columns (1) and (2) the outcome is a dummy equal to one if the company was the target of an M\&A activity in the post-crisis period; in Columns (3) and (4) the outcome is instead a dummy equal to one if the company was a target of an M\&A activity and the company does not exit from the data in the same time frame; in Columns (5) and (6) the outcome is the dummy equal to one if the company exit the data set in the post period; lastly in Columns (7) and (8) the outcome is a dummy if the company exit the data and it reported some financial difficulties before the exit. In all three panels, even columns augment the baseline model with a set of firm level controls measured before the crisis and interacted with the post dummy. These variables are firm size (log of revenue), growth in revenue, cash flow over assets, ROA, and leverage. See the Appendix and the paper for more info on the variables. ${ }^{* *}$ denotes significance at the $1 \%$ level, $* *$ at the $5 \%$, and * at the $10 \%$.

Panel A- Accounting Performance

\begin{tabular}{lcccccc}
\hline & $(1)$ & $(2)$ & $(3)$ & $(4)$ & $(5)$ & $(6)$ \\
& \multicolumn{2}{c}{ Assets Growth } & EBITDA/REV & \multicolumn{2}{c}{ ROA } \\
\hline \multirow{2}{*}{ PE firm x Crisis } & & & & & & \\
& $0.148^{* * *}$ & $0.124^{* * *}$ & -0.009 & -0.010 & -0.003 & -0.004 \\
& $(0.040)$ & $(0.038)$ & $(0.013)$ & $(0.014)$ & $(0.009)$ & $(0.008)$ \\
& & & & & & \\
\hline Year Fixed Effects & Yes & Yes & Yes & Yes & Yes & Yes \\
Firm Fixed Effects & Yes & Yes & Yes & Yes & Yes & Yes \\
Firm Control & No & Yes & No & Yes & No & Yes \\
Observations & 13180 & 12528 & 12507 & 12137 & 12865 & 12364 \\
Clusters & 1984 & 1878 & 1960 & 1878 & 1984 & 1878 \\
R-squared & 0.026 & 0.042 & 0.001 & 0.015 & 0.005 & 0.041 \\
\hline
\end{tabular}


Panel B: Market Share

(1)

(2)

(3)

(4)

(5)

(6)

\begin{tabular}{|c|c|c|c|c|c|c|}
\hline PE firm $x$ Crisis & $\begin{array}{c}0.081 * * \\
(0.035)\end{array}$ & $\begin{array}{c}0.079 * * \\
(0.034)\end{array}$ & $\begin{array}{c}0.050 \\
(0.034)\end{array}$ & $\begin{array}{c}0.055 * \\
(0.033)\end{array}$ & & \\
\hline PE firm x y2004 & & & & & $\begin{array}{c}0.039 \\
(0.057)\end{array}$ & $\begin{array}{c}0.048 \\
(0.059)\end{array}$ \\
\hline PE firm x y2005 & & & & & $\begin{array}{c}0.035 \\
(0.050)\end{array}$ & $\begin{array}{c}0.047 \\
(0.049)\end{array}$ \\
\hline PE firm x y2006 & & & & & $\begin{array}{l}-0.035 \\
(0.036)\end{array}$ & $\begin{array}{l}-0.020 \\
(0.035)\end{array}$ \\
\hline PE firm x y2008 & & & & & $\begin{array}{c}0.094 * * * \\
(0.031)\end{array}$ & $\begin{array}{c}0.106 * * * \\
(0.034)\end{array}$ \\
\hline PE firm x y2009 & & & & & $\begin{array}{c}0.072 * * \\
(0.031)\end{array}$ & $\begin{array}{c}0.088 * * * \\
(0.033)\end{array}$ \\
\hline PE firm x y2010 & & & & & $\begin{array}{c}0.039 \\
(0.037)\end{array}$ & $\begin{array}{c}0.052 \\
(0.039)\end{array}$ \\
\hline PE firm x y2011 & & & & & $\begin{array}{l}-0.007 \\
(0.053)\end{array}$ & $\begin{array}{c}0.005 \\
(0.055)\end{array}$ \\
\hline Sample & \multicolumn{2}{|c|}{ 2004-2009 } & \multicolumn{2}{|c|}{ Whole Sample } & \multicolumn{2}{|c|}{ Whole Sample } \\
\hline Year Fixed Effects & Yes & Yes & Yes & Yes & Yes & Yes \\
\hline Firm Fixed Effects & Yes & Yes & Yes & Yes & Yes & Yes \\
\hline Firm Control & No & Yes & No & Yes & No & Yes \\
\hline Observations & 9090 & 8847 & 12697 & 12326 & 12697 & 12326 \\
\hline Clusters & 1960 & 1878 & 1960 & 1878 & 1960 & 1878 \\
\hline R-squared & 0.035 & 0.087 & 0.021 & 0.064 & 0.021 & 0.064 \\
\hline
\end{tabular}

Panel C - Exit Outcomes

(1)

(2) $1\{\mathrm{M} \& \mathrm{~A}\}$
(3)
(4) Distress $\}$
(5)

(6)

$1\{$ Exit\}
(7)

$1\{$ Bankruptcy\}
(8)

Marginal Eff.

PE Firm

$\begin{array}{cc}0.351 * * * & 0.325 \\ (0.023) & (0.10 \\ \mathrm{Y} & \end{array}$

$\mathrm{Y}$
$\mathrm{Y}$

$0.351 * * *$

$0.318 * * *$

0.058

0.039

0.092

(0.103)

0.099

$\quad(0.024)$

$\begin{array}{lll}(0.100) & (0.085) \quad(0.087)\end{array}$

Y

Y

$\begin{array}{ll}\mathrm{Y} & \mathrm{Y} \\ & \mathrm{Y}\end{array}$

Industry (2-digit) F.E. $\quad$ Y
Firm Controls 2007

Observations

1635

1635

1635

$1635 \quad 1368 \quad 1368$

$\mathrm{Y}$
$\mathrm{Y}$
1368

\begin{tabular}{cc} 
Y & $Y$ \\
& $Y$ \\
1360 & 1360 \\
\hline
\end{tabular}




\section{Appendix}

\section{A.1 Data and variable construction}

Aside from Capital IQ, all the data in the paper come from the Amadeus/Orbis database, produced by Bureau Van Dijk. To minimize the chances that data errors could drive our results, we winsorize at $1 \%$ every ratio and growth rate used in the analysis. The winsorization was undertaken over the full sample of Amadeus/Orbis, companies. All variables in levels are in millions of dollars.

The main variables we used in the analysis are the following: (a) Investment/Assets, where investment is constructed as the change in assets over the past year, plus depreciation; (b) (Net) Equity Contribution/Assets, where the equity contribution is measured as the difference in total equity (shareholder value) over the past year, minus the profit; (c) (Net) Debt Issuance/Assets, where the debt issuance is measured as the overall change in debt; (d) Leverage, which is simply total debt (short- and long-term) divided by assets; (e) ROA, which is net income over assets; (f) EBITDA/Assets, where EBITDA is the earnings before interest, taxes, depreciation, and amortization; (g) the Logarithm of Market Share, where market share is the ratio of the firm revenue in a specific year and the total revenue of all medium and large firms in the same SIC twodigit industry.

In the paper, we use different methodologies to determine companies that are more or less likely to be financial constrained at the time of the financial crisis. First, we use size by looking at the top quartile of revenue in 2007, across the sample. Second, we identify firms that are in the top quartile of leverage in 2007. Third, we identify companies operating in industries that are more dependent on external finance. The index is constructed using all firms in Compustat between 
1980 and 2007: we construct a score for every two digit SIC code, which is the median of CAPEX minus operating cash flow, scaled by CAPEX. 


\section{Figure A.1 : Effect of PE-backed companies over time}

This figure reports the time-varying effect of being a PE-backed company on the main outcomes. Panel A reports the effect on investment, Panel B on debt issuance and Panel C on equity contribution. Specifically, this Figure reports the $\beta_{t}$ of the following equation: $y_{i t}=\alpha_{t}+\alpha_{i}+\beta_{t}\left(P E\right.$ firm $\left._{i}\right)+\varepsilon_{i t}$. As explained in the paper, the year 2007 is used as base period and therefore the corresponding coefficient is normalized to zero. The central dot reports the point estimate while the straight vertical lines report the $90 \%$ confidence interval. The confidence interval is constructed using standard errors clustered at firm level. More info on this measure is available in the paper and in the Appendix.

\section{Panel A - Investment}

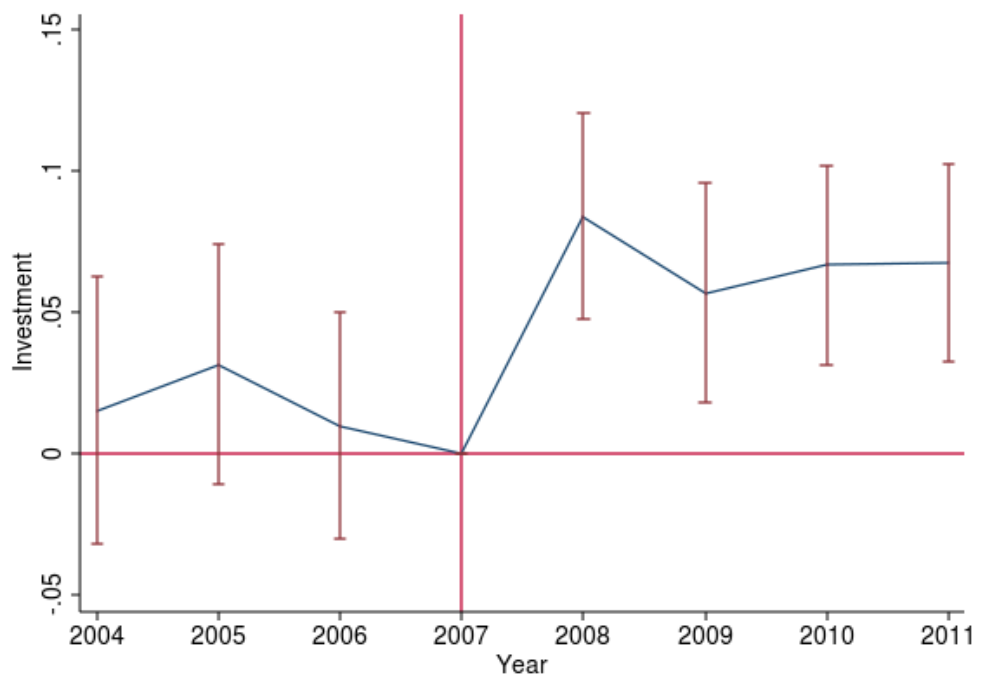

\section{Panel B - Equity Contributions}

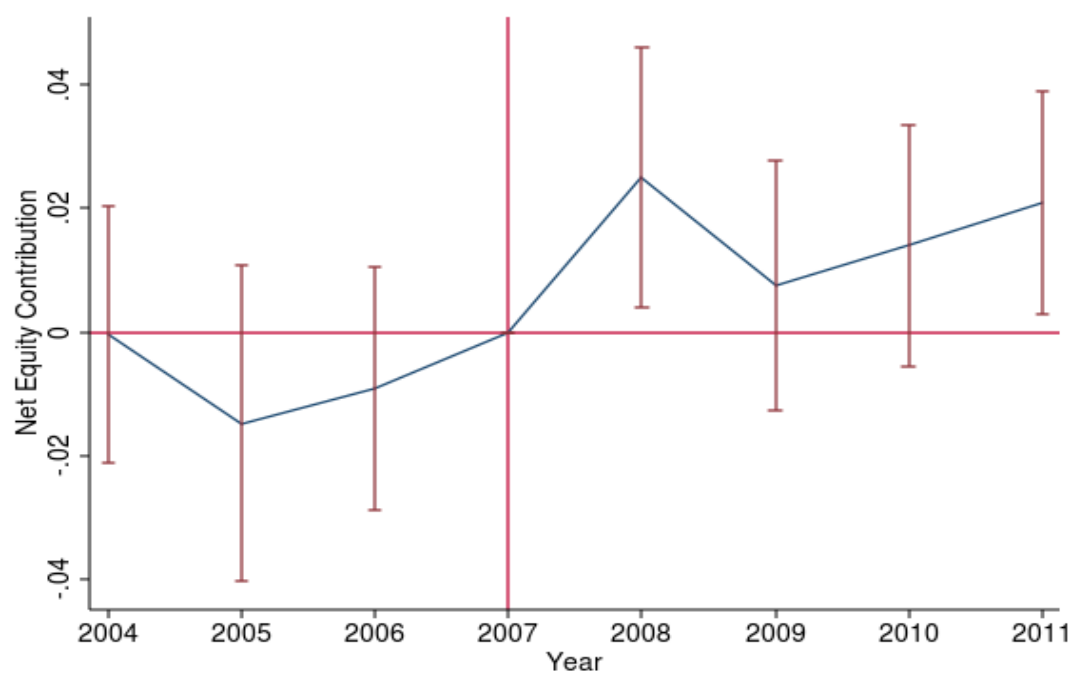


Panel C - Debt Issuance.

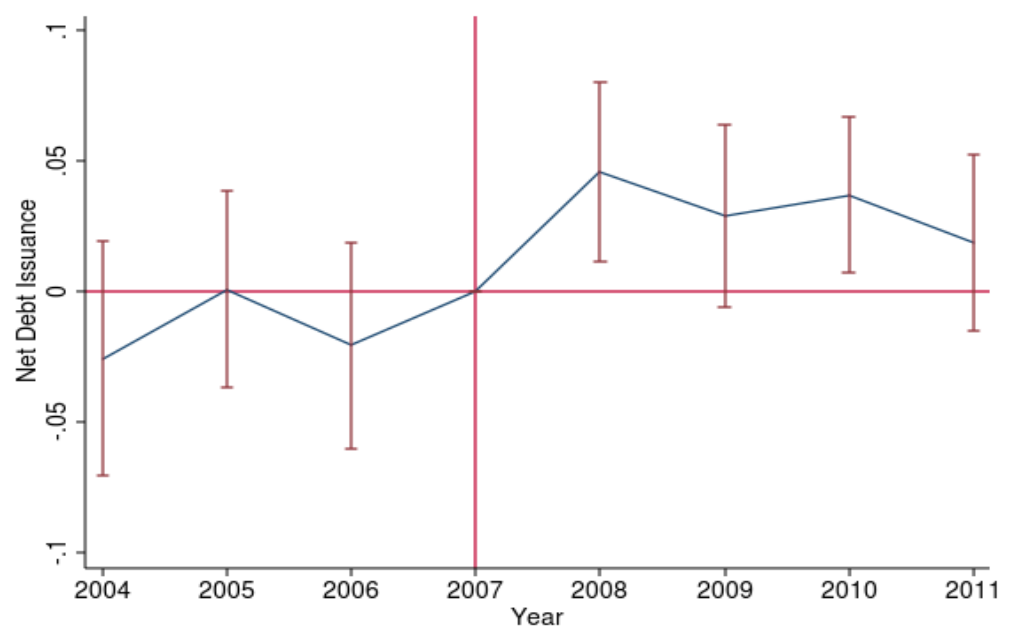




\section{Table A.1: Robustness excluding MBO}

This Table reports a robustness test, where we estimate the standard difference-in-difference fixed effect model on the main outcome variables dropping the PEbacked companies whose deal is identified as a management buyout (MBO) and the corresponding matched companies. Every specification contains a set of firm and year fixed effects. The main parameter of interest is the interaction between the crisis dummy and a dummy identifying PE-backed companies. Odd columns contain the baseline regression where instead even columns augment the baseline model with a set of firm level controls measured before the crisis and interacted with the post dummy. These variables are firm size (log of revenue), growth in revenue, cash flow over assets, ROA, and leverage. In Columns (1) and (2) the outcome is investment scaled by assets; in Columns (3) and (4) is net equity contribution; in Columns (5) and (6) is the net debt issuance; in Columns (7) and (8) is leverage; in Columns (9) and (10) is ROA. More information on the variables is available in the Appendix. Standard errors are clustered at firm level. *** denotes significance at the $1 \%$ level, $* *$ at the $5 \%$, and $*$ at the $10 \%$.

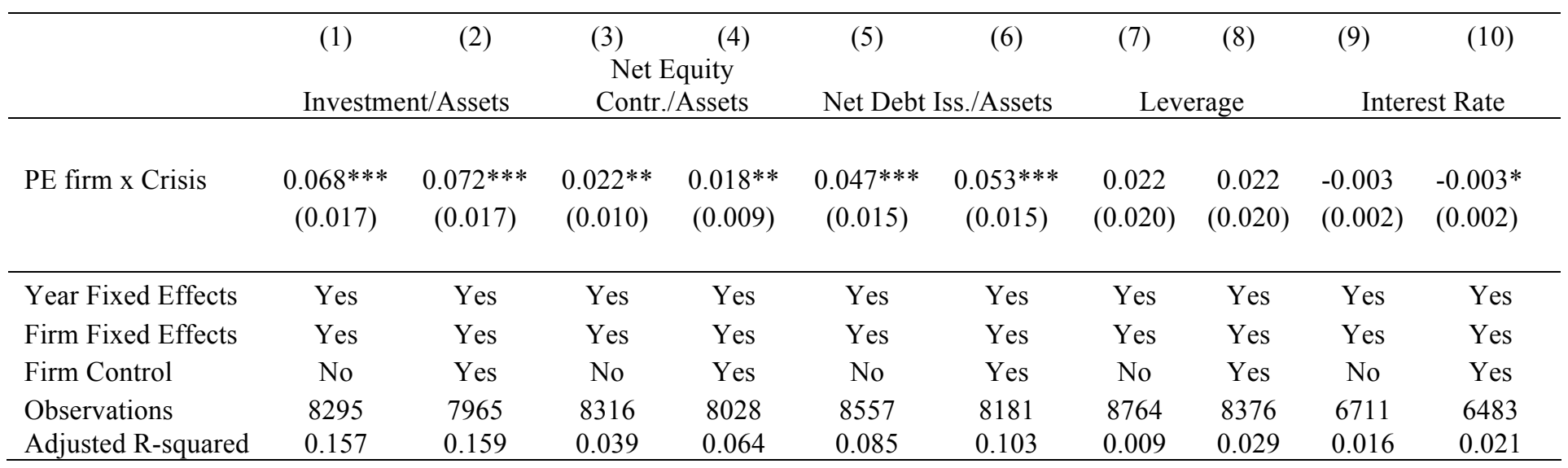


Table A.2: Robustness using only 2007-2008

This table reports a robustness test, where we estimate the standard difference-in-difference fixed effect model on various outcomes using only data from 2007 and 2008. This corresponds to the last year before the crisis and the first one in the crisis. Every specification contains a set of firm and year fixed effects. The main parameter of interest is the interaction between the post dummy and a dummy identifying PE-backed companies. Odd columns contain the baseline regression where instead even columns augment the baseline model with a set of firm level controls measured before the crisis and interacted with the post dummy. These variables are firm size (log of revenue), growth in revenue, cash flow over assets, ROA, and leverage. In Columns (1) and (2) the outcome is investment scaled by assets; in Columns (3) and (4) is net equity contribution; in Columns (5) and (6) is the net debt issuance; in Columns (7) and (8) is leverage; abd in Columns (9) and (10) is ROA. More information on the variables is available in the Appendix. Standard errors are clustered at firm level. *** denotes significance at the $1 \%$ level, $* *$ at the $5 \%$, and $*$ at the $10 \%$.

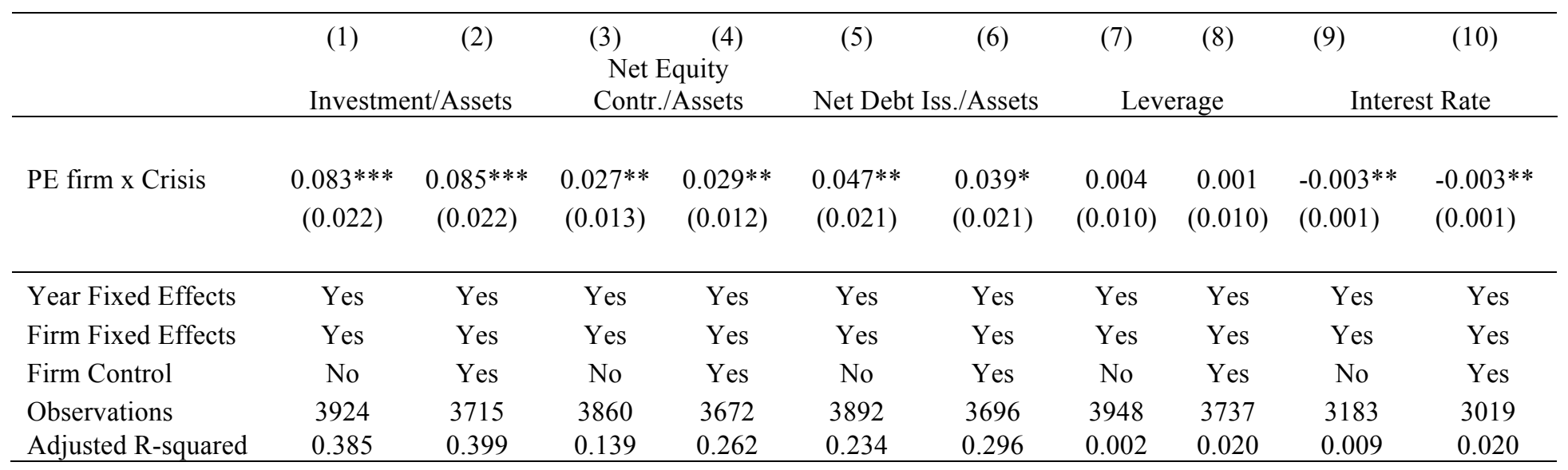


Table A.3: Robustness using only companies not experiencing exit

This table reports a robustness test, where we estimate the standard difference-in-difference fixed effect model on various outcomes using only data only for groups of matched firms where no company is identified as leaving the data by 2011 (survivorship bias free). Every specification contains a set of firm and year fixed effects. The main parameter of interest is the interaction between the post dummy and a dummy identifying PE-backed companies. Odd columns contain the baseline regression where instead even columns augment the baseline model with a set of firm level controls measured before the crisis and interacted with the post dummy. These variables are firm size (log of revenue), growth in revenue, cash flow over assets, ROA, and leverage. In Columns (1) and (2) the outcome is Investment scaled by asset; in Columns (3) and (4) is net Equity Contribution; in Columns (5) and (6) is the net Debt Issuance; in Columns (7) and (8) is leverage; in Columns (9) and (10) is ROA. More information on the variables is available in the Appendix. Standard errors are clustered at firm level. *** denotes significance at the $1 \%$ level, ** at the $5 \%$, and $*$ at the $10 \%$.

\begin{tabular}{|c|c|c|c|c|c|c|c|c|c|c|}
\hline & \multicolumn{4}{|c|}{$\begin{array}{c}\text { Net Equity } \\
\text { Contr./Assets }\end{array}$} & Net Debt & s./Assets & \multicolumn{2}{|c|}{ Leverage } & \multicolumn{2}{|c|}{ Interest Rate } \\
\hline$P E$ firm $x$ Crisis & $\begin{array}{c}0.044 * * * \\
(0.014)\end{array}$ & $\begin{array}{c}0.040 * * * \\
(0.014)\end{array}$ & $\begin{array}{c}0.017 * * \\
(0.008)\end{array}$ & $\begin{array}{c}0.016 * * \\
(0.008)\end{array}$ & $\begin{array}{c}0.030 * * \\
(0.013)\end{array}$ & $\begin{array}{c}0.025 * * \\
(0.012)\end{array}$ & $\begin{array}{c}0.003 \\
(0.014)\end{array}$ & $\begin{array}{c}0.000 \\
(0.014)\end{array}$ & $\begin{array}{l}-0.002 \\
(0.001)\end{array}$ & $\begin{array}{l}-0.003 * \\
(0.001)\end{array}$ \\
\hline Year Fixed Effects & Yes & Yes & Yes & Yes & Yes & Yes & Yes & Yes & Yes & Yes \\
\hline Firm Fixed Effects & Yes & Yes & Yes & Yes & Yes & Yes & Yes & Yes & Yes & Yes \\
\hline Firm Control & No & Yes & No & Yes & No & Yes & No & Yes & No & Yes \\
\hline Observations & 9658 & 9271 & 9700 & 9367 & 10020 & 9567 & 10242 & 9776 & 7963 & 7683 \\
\hline Adjusted R-squared & 0.160 & 0.160 & 0.046 & 0.061 & 0.090 & 0.102 & 0.029 & 0.040 & 0.020 & 0.026 \\
\hline
\end{tabular}




\section{Table A.4: Robustness adding time-varying industry fixed effects}

This table reports a robustness test, where we estimate the standard difference-in-difference fixed effect model on various outcomes adding set of fixed effects generated as the product of industry (two digit SIC) and the post dummy. Every specification contains a set of firm and year fixed effects. The main parameter of interest is the interaction between the post dummy and a dummy identifying PE-backed companies. Odd columns contain the baseline regression where instead even columns augment the baseline model with a set of firm level controls measured before the crisis and interacted with the post dummy. These variables are firm size (log of revenue), growth in revenue, cash flow over assets, ROA, and leverage. In Columns (1) and (2) the outcome is investment scaled by asset; in Columns (3) and (4) is net equity contribution; in Columns (5) and (6) is the net debt issuance; in Columns (7) and (8) is leverage; and in Columns (9) and (10) is ROA. More information on the variables is available in the Appendix. Standard errors are clustered at firm level. *** denotes significance at the $1 \%$ level, $* *$ at the $5 \%$, and $*$ at the $10 \%$.

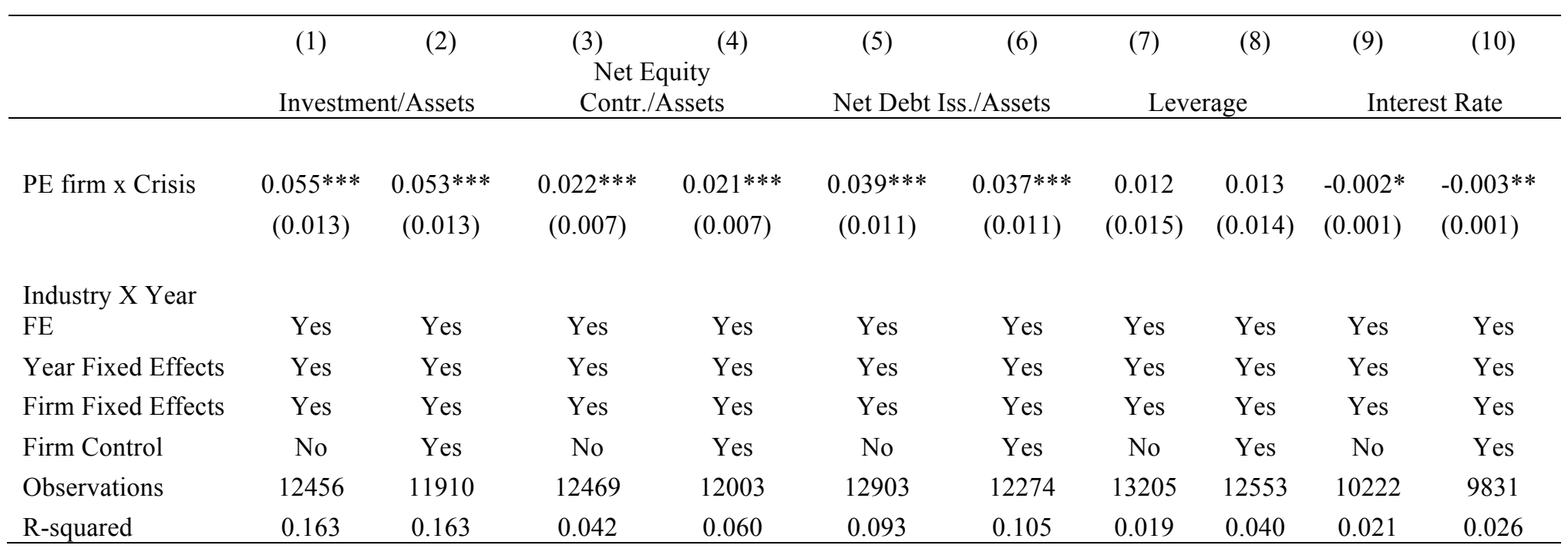




\section{Table A.5: Robustness of Market Share Results}

This table reports a robustness test on the market share results. All regressions are cross-sectional regressions, where we compare firms across PE and non-PE backed companies. In Columns (1)-(4), we estimate a conditional logit model, where the outcome is a dummy equal to one if the market share of the firm increased over 2009 and 2007 (Columns 1 and 2) or over 2011 and 2007 (Columns 3 and 4). The reported beta are marginal effect at the average and the model is estimated with SIC two-digit fixed effects. In Columns (5)-(8), we estimate an OLS model where the outcome is the growth rate in market share between 2009 and 2007 (Columns 5 and 6) or 2011 and 2007 (Columns 7 and 8 ). The market share growth is winsorized at $1 \%$ to reduce the influence of outliers. Odd columns contain the baseline regression where instead even columns augment the baseline model with a set of firm level controls measured before the crisis and interacted with the post dummy. These variables are firm size (log of revenue), growth in revenue, cash flow over assets, ROA, and leverage. More information on the variables is available in the Appendix. Standard errors are clustered at firm level. *** denotes significance at the $1 \%$ level, ** at the $5 \%$, and * at the $10 \%$.

\begin{tabular}{|c|c|c|c|c|c|c|c|c|}
\hline & $(1)$ & $(2)$ & (3) & $(4)$ & $(5)$ & $(6)$ & (7) & (8) \\
\hline & \multicolumn{4}{|c|}{ Market Share Increase - Dummy } & \multicolumn{4}{|c|}{ Market Share Growth } \\
\hline & \multicolumn{2}{|c|}{$2007-2009$} & \multicolumn{2}{|c|}{ 2007-2011 } & \multicolumn{2}{|c|}{$2007-2009$} & \multicolumn{2}{|c|}{ 2007-2011 } \\
\hline PE Firm & $\begin{array}{c}0.054 * * \\
(0.024)\end{array}$ & $\begin{array}{l}0.032 * \\
(0.018)\end{array}$ & $\begin{array}{c}0.042 \\
(0.027)\end{array}$ & $\begin{array}{c}0.017 \\
(0.012)\end{array}$ & $\begin{array}{l}0.046^{*} \\
(0.027)\end{array}$ & $\begin{array}{c}0.063 * * \\
(0.031)\end{array}$ & $\begin{array}{c}0.027 \\
(0.049)\end{array}$ & $\begin{array}{r}0.054 \\
(0.050)\end{array}$ \\
\hline $\begin{array}{l}\text { Industry (2-digit) } \\
\text { F.E. }\end{array}$ & Y & Y & Y & Y & Y & Y & Y & Y \\
\hline Firm Controls 2007 & & Y & & Y & & Y & & $\mathrm{Y}$ \\
\hline Observations & 1639 & 1639 & 1564 & 1564 & 1655 & 1655 & 1565 & 1565 \\
\hline
\end{tabular}

